\title{
Homeownership in the 1980s and 1990s: Aggregate Trends and Racial Gaps
}

\author{
Stuart A. Gabriel \\ Department of Finance and Business Economics and Lusk Center for Real Estate \\ 331 Lewis Hall \\ University of Southern California \\ Los Angeles, California 90089-1421 \\ Phone: (213) 740-6523 \\ Email: sgabriel@marshall.usc.edu \\ and \\ Stuart S. Rosenthal \\ Department of Economics \\ Center for Policy Research \\ Syracuse University \\ Syracuse, New York 13244-1090 \\ Phone: (315) 443-3809 \\ Email: ssrosent@,maxwell.syr.edu
}

September 14, 2004

We thank Jim Freund, Francois Ortalo-Magne, seminar participants at the Federal Reserve Bank of Philadelphia, and two anonymous referees for helpful comments. Funding from the Mortgage Bankers Association of America is gratefully acknowledged. Any remaining errors are our own. 


\begin{abstract}
Housing policy under the Clinton and Bush Administrations has sought to boost homeownership while also narrowing racial gaps in owner-occupancy rates. Against that backdrop, homeownership rose sharply in the 1990s, but white-minority gaps remain in excess of 25 percentage points. We analyze these patterns using data from the 1983 to 2001 Survey of Consumer Finances. Results indicate that household characteristics explain most of the increase in homeownership and roughly two-thirds of the white-minority homeownership gap. Credit barriers account for no more than 5 percentage points of the remaining gap. This suggests that policy makers will need to look beyond innovations in mortgage finance if their goal is to further expand homeownership.
\end{abstract}




\section{Introduction}

Over much of the last decade, federal housing policy has focused on two complementary goals. One is to elevate aggregate homeownership rates, while the other is to narrow sizable and persistent racial gaps in homeownership. In 1994, President Clinton made these goals a cornerstone of his administration's housing policy, writing to HUD Secretary Henry Cisneros:

\section{"...Homeownership strengthens families and stabilizes communities. ... Today, I am requesting that you lead an effort to dramatically increase homeownership in our nation over the next six years. ... Your program should include strategies to ensure that families currently underrepresented among homeowners - particularly minority families, young families, and low-income families - can partake of the American Dream." \\ Letter from President Clinton to HUD Secretary Henry Cisneros, November 3, 1994.}

In this letter, President Clinton clearly articulates his belief that homeownership is good for families, neighborhoods, and the economy. President Clinton also emphasizes that special attention should be paid to homeownership rates among underrepresented and disadvantaged groups, including minorities, young people, and low-income families.

Like his predecessor, President Bush also has made homeownership an important goal of domestic housing policy, especially as relates to long-standing disparities in homeownership rates between white and non-white households. ${ }^{2}$ On June 18, 2002, for example, President Bush released the following statement:

\footnotetext{
${ }^{1}$ See http://www.pragueinstitute.org/housing us.htm for the full text of the President's letter and related commentary.

${ }^{2}$ In their efforts to boost homeownership rates, Presidents Clinton and Bush have both continued a tradition of Federal support for homeownership. For many years, for example, Federal tax policy has heavily subsidized homeownership through deductions for mortgage interest and property tax payments as well as through the absence of any tax on imputed rent (e.g. Rosen [25], [26]). Homeownership attainment has also been boosted by the creation of government-sponsored enterprises in both the primary and secondary mortgage markets, including Freddie Mac and Fannie Mae. See also, Haurin et al [12] for an extensive review of homeownership policies.
} 
"The goal is that everybody who wants to own a home has got a shot at doing so. The problem is we have what we call a homeownership gap in America. Threequarters of Anglos own their homes, and yet less than 50 percent of African Americans and Hispanics own homes. That ownership gap signals that something might be wrong in the land of plenty. And we need to do something about it."

President George Bush, June 18, 2002. ${ }^{3}$

This paper draws on data from the Federal Reserve Board's Survey of Consumer Finances (SCF) to analyze the determinants of aggregate trends and long-standing racial gaps in homeownership. Our study period covers the years from 1983 to 2001 . Homeownership rates over this period are shown in Table 1 and also are plotted in Figure 1 to facilitate review. ${ }^{4}$ Observe that homeownership rates edged up one-half percentage point from 1983 to 1989, and then rose a remarkable 3.5 percentage points over the subsequent twelve years to 67.5 percent in 2001. ${ }^{5}$ Despite these dramatic increases in homeownership, in 2001, white-black and whiteHispanic homeownership gaps stood at roughly 26 and 30 percentage points, respectively. Moreover, the white-minority gap in homeownership changed little over the 1990s. Partly in response to those patterns, President Bush has set a goal of 5.5 million new minority homeowners by $2010 .^{6}$

\footnotetext{
${ }^{3}$ See http://www.whitehouse.gov/news/releases/2002/06/20020618-1.html for the full text of the President's remarks.

${ }^{4}$ All values in Table 1 are weighted so as to be representative of the U. S. population.

${ }^{5}$ This rise is consistent with widely reported increases in homeownership rates in the Consumer Population Survey. See, for example: http://www.census.gov/hhes/www/housing/hvs/q103tab5.html .

6، Today, President Bush announced a new goal to help increase the number of minority homeowners by at least 5.5 million before the end of the decade. The President's aggressive housing agenda will help dismantle the barriers to homeownership by providing down payment assistance, increasing the supply of affordable homes, increasing support for self-help homeownership programs, and simplifying the home buying process \& increasing education." White House Press Release, June 17, 2002, http://www.whitehouse.gov/news/releases/2002/06/20020617.html .
} 
Numerous explanations have been offered for the dramatic increase in homeownership in the 1990s, as well as the persistent and large racial gaps in homeownership. On the one hand, the sharp increase in homeownership over the past decade coincided with several important changes in the U.S. economy, including the aging of the baby boomers, the economic boom of the 1990s, and the decline in mortgage interest rates to historically low levels. At the same time, a number of studies have emphasized that the relatively lower economic status of minorities has limited their ability to become homeowners. ${ }^{7}$

The 1990s also witnessed considerable innovation in mortgage finance. In part, this was prompted by prominent media accounts in the late 1980s and a related report by the Federal Reserve Bank of Boston that heightened concerns regarding unfair denial of mortgage credit to minorities (see Munnell et al [21], Ross and Yinger [29], Turner et al. [30]). ${ }^{8}$ These concerns contributed to tighter government oversight of the mortgage industry as well as to the introduction of a variety of new mortgage products that had the effect of relaxing loan underwriting standards. ${ }^{9}$ This was especially true for minority and other low-income, lowwealth families that might have previously lacked sufficient downpayment. It is tempting to ascribe significant portions of the increase in homeownership in the 1990s to these expansions in

\footnotetext{
${ }^{7}$ See, for example, Wachter and Megbolugbe [32], Gyourko and Linneman [11], Coulson [5], Painter, Gabriel, and Myers [22], Gabriel and Painter [9], Haurin et al [12].

${ }^{8}$ In May 1988, the Atlanta Constitution published a four part series, "The Color of Money," while the Detroit Free Press published a similar series in July 1988. Those and like analyses of Home Mortgage Disclosure Act (HMDA) data showed that mortgage application rejection rates for African Americans in 1990 were about 2-1/2 times larger than those for white households with similar income.

${ }^{9}$ For example, beginning in 1990 , lenders were required by HMDA to report the location of residential loans made along with the income, race, and gender of loan applicants and whether the loan application was withdrawn (by the applicant), approved, or denied. See Rehm [23, 24], Canner and Smith [4], and Munnell et. al.[21] for further discussion of the HMDA data. In addition, mortgage products such as Zero Down ${ }^{\mathrm{TM}}$ have become available. This is an affordable mortgage product newly offered by Bank of America that is now available in numerous states. It is a is a conventional mortgage that requires zero downpayment. In addition, closing costs can come from a gift, the seller, or can be financed (see Bank of America [2]).
} 
the availability of credit. Indeed, Governor Gramlich of the Federal Reserve Board did just that in a recent speech to mortgage industry officials and other housing specialists at a meeting sponsored by the Financial Services Roundtable. ${ }^{10}$

“... Overall homeownership rates have gone from 64 percent to more than 68 percent over this period [1994-2003]. ... A major portion of this expansion in homeownership seems clearly attributable to the increased access to credit afforded by expansions in prime and subprime mortgage lending."

Remarks by Governor Edward M. Gramlich at the Financial Services Roundtable Annual Housing Policy Meeting, Chicago, Illinois, May 21, 2004.

A central goal of this paper is to measure the extent to which changes in the distribution of population socioeconomic attributes account for recent patterns in homeownership, and to compare those effects to the influence of changes in the macroeconomic environment and lending conditions. To conduct our analysis, we draw on household level data from the Federal Reserve Board's Survey of Consumer Finances for the years 1983, 1989, 1992, 1995, 1998, and 2001. These surveys are primarily independent cross-sections and provide exceptionally rich information on individual household financial and demographic characteristics, including access to credit. ${ }^{11}$ We use these surveys in a series of exercises designed to analyze the determinants of trends in homeownership rates over the period.

In the first exercise, simple probit models are estimated separately for each survey year based on whether families own or rent their primary homes. A shift-share analysis is then employed to simulate the degree to which homeownership rates in 2001 would have differed had families in that year behaved as in prior survey years. This is accomplished by holding constant the year 2001 sample while applying coefficient estimates from the previous years. Assuming

\footnotetext{
${ }^{10}$ See, http://www.federalreserve.gov/boarddocs/speeches/2004/20040521.htm for the complete text of Governor Gramlich's speech.

${ }^{11}$ The 1983 and 1989 surveys have a partial panel component that we do not draw upon in the analysis.
} 
that tastes for homeownership remain unchanged, coefficients from different years capture the influence of year-specific macroeconomic and lending market conditions that affect housing tenure decisions, including interest rates, business cycle risk and uncertainty, and innovations in housing policy and mortgage finance. In a second exercise, we simulate the degree to which homeownership rates in the pre-2001 survey years would have differed if families in those years had behaved as in 2001 . This is accomplished by holding constant the year 2001 model coefficients but applying the sample characteristics from the previous years. In this instance, the year-2001 coefficients capture the influence of lending market and macroeconomic conditions in 2001, while differences in sample attributes from the prior survey years allow for changes in the socio-demographic attributes of the population over time.

The analysis then turns to an assessment of racial gaps in homeownership. To do so, we decompose racial gaps into three parts: a portion that can be attributed to differences in household attributes apart from race (e.g. income, age, marital status), a portion that can be attributed to the influence of credit barriers, and a residual that reflects factors not captured by the model specification. Decomposing racial gaps in this manner is difficult because it requires that we first identify a priori a group of households that are not credit constrained, in the sense that they hold as much debt as they would like at prevailing market interest rates. We do this by using a series of SCF survey questions that enable us to identify a group of families that are not constrained by lender credit limits. Jappelli [15], Cox and Jappelli [6], Duca and Rosenthal [7, 8] and Rosenthal [28] also use these SCF survey questions to study credit barriers. The homeownership decisions of the unconstrained families are then estimated controlling for sample selection, and coefficients are compared to those from a full sample model that does not take credit barriers into account. We show that differencing the race-related coefficients from these 
two models provides an estimate of the impact of credit barriers on racial gaps in homeownership. Details of this procedure, as well as a description of alternative approaches in the literature, are provided later in the paper.

Results indicate that most of the increase in homeownership in the 1990s can be attributed to changes in the demographic and economic attributes of the population. In addition, in the late 1990 s, differences in population attributes explain all but approximately 8 percentage points of the roughly 26 percentage point white-black gap in homeownership and all but about 10 percentage points of the roughly 30 percentage point white-Hispanic gap. Of the remaining differentials, credit barriers account for no more than 5 percentage points of the white-minority gaps in homeownership, both in 2001 and also in each of the survey years back to 1983. An important implication of these findings is that the gain in homeownership in the 1990s appears to have been driven primarily by household demographic factors that had little to do with government and industry initiatives. These same demographic factors also explain much of the persistent racial gap in homeownership.

To establish these and related results, the following section describes the SCF data. Section 3 discusses various modeling issues. Section 4 analyzes changes in aggregate homeownership rates over the 1983 to 2001 period based on a series of probit models. Section 5 analyzes racial gaps in homeownership taking credit barriers into account. Section 6 provides robustness checks and Section 7 concludes.

\section{Survey of Consumer Finances Data}

Our primary data for the analysis are taken from the Survey of Consumer Finances (SCF) for the years 1983, 1989, 1992, 1995, 1998, and 2001. These surveys are independent crosssections with the exception of the 1983 and 1989 surveys for which a portion of the 1983 families 
appear again in 1989. In addition, beginning in 1989, a sophisticated procedure is used to impute missing values and also to protect the confidentiality of respondents. In part, this includes the creation of five "implicates" of the data, where each is an alternate version of the entire dataset but with slightly different imputations. Kennickell [17] provides details on how to interpret and work with the Implicates. When estimating the probit models presented later in the paper, only the first implicate is used. This avoids any artificial increase in sample size and related reduction in the estimated model standard errors. ${ }^{12}$

For a typical SCF sample of about 4,500 households, roughly 3,000 are selected so as to be representative of the entire United States while the remaining households over-represent wealthy families and are drawn from tax files. For the 1983 survey, these sub-samples can be identified and only the representative portion of the sample was used for the analysis to follow. For all other survey years, the public use versions of the SCF do not allow the analyst to separately identify the representative and tax-based samples. However, sampling weights are provided that enable the analyst to weight the data to ensure that results are representative of the United States. ${ }^{13}$ In the discussion to follow, all of the probit models were estimated using unweighted data on the assumption that all covariates in the model are exogenous. In contrast, all summary measures including the simulation values were calculated using the sampling weights so as to be representative of the United States. Finally, it should also be noted that all dollar-valued variables were converted to 2001 dollars. In addition, we exclude any observations for which total income

\footnotetext{
${ }^{12} \mathrm{An}$ alternative approach is to include all five implicates and then divide the t-ratios by the square root of 5 to adjust for the "true" sample size. See the SCF manual and Kennickell [17] for details.

${ }^{13}$ Kennickell [16] provides a careful discussion of the SCF sampling weights and shows that the sample moments of the weighted SCF data with regard to homeownership rates and race match the Consumer Population Survey (CPS). See also Rosenthal [27] for further discussion of the SCF.
} 
is missing or above $\$ 1,000,000$ (in 2001 dollars). ${ }^{14}$ Weighted sample means for all of the variables used in the analyses are presented in the Appendix for each survey year.

\section{Modeling Issues}

The literature on housing tenure choice and homeownership is substantial (see Haurin et al [12] for a recent review) and has identified numerous factors that influence the propensity of individual families to own versus rent their homes. Two closely related conceptual paradigms stand out in this literature. Henderson and Ioannides [13] explicitly recognize that homeownership is both an investment that contributes to a household's portfolio, and also a consumption good that provides shelter. They argue that if the investment demand for housing exceeds consumption demand, families are more likely to own their primary residence. This is because owner-occupiers can, in principle, rent out that portion of their real estate holdings not desired for personal use. However, if investment demand is less than consumption demand, then owner-occupying a level of housing sufficient to accommodate a family's demand for shelter would comprise a bad investment. Under these conditions, a viable alternative is to rent. ${ }^{15}$

A closely related idea pertains to the user cost of owner-occupied housing. This idea has its origins in early work by Laidler [19] Aaron [1], and Rosen [25]. Factors that influence the user cost of owner-occupied housing include depreciation, maintenance, property taxes, expected capital gains, interest rates, and the household's marginal income tax rate. ${ }^{16}$ Also important is

\footnotetext{
${ }^{14}$ Especially at the upper end, the SCF includes a small number of extremely high-income households and these individuals are removed from the sample to ensure that they do not unduly influence the results.

${ }^{15}$ Building on this intuition, Henderson and Ioannides [13] argue that the divergence between investment and consumption demand for real estate should be an important determinant of whether families choose to own versus rent their homes. Empirical support for this idea has been provided by Ioannides and Rosenthal [14].

${ }^{16}$ This latter term is important because it affects the value of housing related deductions (e.g. mortgage interest and property tax payments) as well as the failure to tax imputed rent.
} 
the household's anticipated length of stay in the home as that affects the annualized cost of realtor and legal fees paid by owner-occupiers upon buying and selling a home. ${ }^{17}$ Finally, spatial variation in the quality adjusted price and rent on a home further affect the relative cost of owning to renting. An extensive literature has demonstrated that, all other things equal, households are more likely to own their primary residence as the user cost of owner-occupied housing falls (e.g. Rosen $[25,26])$.

In the empirical work to follow, we do not formally model either homeowner user costs or the divergence between the investment and consumption demands for real estate. Instead, we begin by estimating a series of simple reduced form probit models of whether a household owns its current home as a function of household demographic and financial attributes. This approach is also common in the literature and is adopted here for two reasons in particular. ${ }^{18}$ From a data standpoint, a well-specified measure of user cost would include the quality adjusted house priceto-rent ratio in the local MSA. However, the public use version of the SCF does not identify a household's location with sufficient precision to measure these variables. Instead, for select survey years, the SCF makes available information on household location with regard to four regions of the country and also the density of the local neighborhood. We use these variables to proxy for the local quality adjusted price and rent for housing in some of the models presented below.

In addition, from a conceptual standpoint, the key question posed in this paper is the extent to which changes in household attributes account for trends in homeownership rates as

\footnotetext{
${ }^{17}$ Rosenthal [27] extends the user cost framework to allow for realtor and legal fees incurred by homeowners. The annualized cost of those fees diminish with length of stay in the home.

${ }^{18}$ See, for example, Gabriel and Rosenthal [10], Haurin et al [12]).
} 
well as longstanding racial gaps in homeownership. For both the investment/consumption model and the user cost approach, variation in the propensity for homeownership is driven by variation in local economic conditions (e.g. market risk, prices and rents), as well as several factors that ultimately are determined by household attributes. These latter factors include tastes for investment risk since housing is a risky asset in many markets, marginal income tax rates, and the rate at which the household discounts future returns. In the regressions to follow, coefficients on household characteristics including age, marital status, income, and the like, capture both the direct impact of these factors on tastes for homeownership, as well as indirect effects through their influence on user cost and the investment demand for real estate. In this way, our reduced form probit models enable us to identify the full impact of household attributes on homeownership, consistent with the goals of this paper.

\section{Aggregate Homeownership Rates}

A probit model is estimated separately for each of the SCF survey years from 1983 to 2001. Partial derivatives associated with the individual probit model coefficients are computed for each observation and the weighted sample means are reported in Table $2 .{ }^{19}$ Accordingly, the reported values indicate the percentage point influence of a given household attribute on the propensity for homeownership. The numbers in parentheses are t-ratios from the original probit model coefficients.

\footnotetext{
${ }^{19}$ When calculating the mean partial derivative for a given covariate we used sampling weights since the sample mean depends on the distribution of individuals in the sample. In addition, for a given 1-0 dummy variable, $X_{1-0}$, derivatives were obtained by calculating the unconditional probability of owning first with $X_{1-0}$ set equal to 1 , again with $X_{1-0}$ set equal to 0 , and then differencing the results. For all other variables, derivatives were formed as $f(\mathrm{x} b) b$, where $f$ is the probability density function for the standard normal distribution and $b$ is the probit model tenure coefficient.
} 
As is evident in Table 2, our set of household attributes is extensive, and a number of these attributes have strong and anticipated effects on homeownership. ${ }^{20}$ For example, in nearly all of the survey years, the propensity for homeownership is higher for household heads that are married or divorced. Homeownership also increases with the age of the household head, household size, income, receipt of an inheritance, full-time work, and stable employment, the latter of which is inversely related to the number of previous full-time jobs held by the household head. In contrast, the propensity for homeownership is reduced if the household head is in poor health or of minority status.

The estimates in Table 2 are used to shed light on the first major goal of this paper, to assess the extent to which changes in household socio-economic status contributed to the increase in homeownership rates in the 1990s. To accomplish that goal, in a first set of simulations, we compute homeownership rates for each survey year by combining the data from a given year with the estimated 2001 probit model coefficients in Table 2 . In viewing the results of this exercise, we emphasize that the year-2001 coefficients embody the response of households to market conditions in that year, including mortgage market opportunities and broader macroeconomic conditions. In addition, as noted earlier, all simulations are carried out applying sampling weights to ensure that the results are representative of the United States. Accordingly, this simulation sheds light on the degree to which changes in household attributes contributed to change in homeownership rates in the 1990s, holding constant the economic environment of 2001. In a second set of simulations, we hold constant the year 2001 data, but apply that data to probit model coefficients from each of the survey years. This simulation sheds light on the degree to which changes in household behavior - as embodied in the individual model-year coefficients - contributed to the change in homeownership rates. Assuming that

\footnotetext{
${ }^{20}$ See, for example, Wachter and Megbolugbe [31], Coulson [5], Rosenthal [28], Gabriel and Painter [9]).
} 
tastes for homeownership are constant over time, this simulation captures the influence of changes in broad economic conditions on homeownership rates, including innovations in mortgage finance, business cycle risk, market prices, and the like.

Figure 2a plots the predicted homeownership rates from these two simulations. Consider first the simulation in which we hold constant the year 2001 model coefficients while varying the sample composition across years. In that simulation, the predicted homeownership rate falls from 64.3 percent in 1983 to 63.0 percent in 1989 , but then rises continuously to a peak of 67.5 in 2001. This implies that changes in the demographic and financial attributes of the population boosted homeownership rates by 4.5 percentage points between 1989 and 2001. A very different pattern emerges when we hold constant the year 2001 sample but apply the estimated model coefficients from the different survey years. In that case, changes in model coefficients imply a sharp 2 percentage point increase in homeownership rates from 1983 to 1989, a period in which adjustable-rate mortgages became widely available and mortgage rates experienced dramatic declines. Thereafter, however, predicted homeownership rates trend down slightly over the decade of the 1990s.

Summarizing the patterns in Figure 2a, it appears that the increase in homeownership rates in the 1990s was driven largely by changes in the socio-economic status of the population over that period. In contrast, coefficient estimates from the probit models provide little evidence that changes in housing finance and other macroeconomic factors - as embodied in the estimated model coefficients - served to boost homeownership during the 1989 to 2001 period. 


\section{Racial Gaps in Homeownership}

As described in the Introduction, recent years also have witnessed ongoing controversy and policy debate about long-standing and sizable racial gaps in homeownership. These concerns have contributed to a multitude of industry and policy initiatives, including measures designed to ease underwriting standards that have restricted access to mortgage credit. Against that backdrop, this section estimates the degree to which racial gaps can be attributed to both differences in household attributes and the influence of credit barriers.

We begin by explaining how the influence of credit barriers is identified. As noted earlier, this is difficult as it requires that one identify, a priori, a group of households that are not credit constrained, and then use the behavior of that group to infer how others would have behaved in the absence of binding credit limits, ceteris paribus. Two methods have evolved in the literature to address this challenge.

In the first approach (e.g. Zorn [33] and Lineman and Wachter [18]), analysts specify a priori a set of underwriting standards, for example, by setting loan-to-value (LTV) limits to 80 percent. Individuals with LTV ratios in excess of the specified limit are then assumed to be credit constrained and are treated differently from other households in the sample. This approach is appealing because it takes prior knowledge of underwriting standards explicitly into account. That is especially important if the goal is to estimate the relative impact of different underwriting standards. ${ }^{21}$ But this approach also suffers from potentially serious measurement error. That is because primary market underwriting standards are typically unobserved and likely differ across lenders and loan applicants. As a result, it is difficult to be confident as to

\footnotetext{
${ }^{21}$ For example, using data from the 1980s, Lineman and Wachter [18] conclude that LTV limits reduce homeownership propensities to a greater degree than do house payment-to-income limits, although both constraints are found to be important.
} 
whether any group of households are properly classified with regard to the influence of credit barriers, regardless of whether families are characterized as credit constrained or not constrained. As an alternative, a different set of studies (e.g. Jappelli [15], Cox and Jappelli [6], Duca and Rosenthal [7, 8], and Rosenthal [27]) do not directly specify the borrowing limits imposed by lenders on individual households. Instead, these studies draw on a special feature of the SCF that enables analysts to identify a priori a group of households that appear to be unaffected by credit constraints. Households are asked a battery of questions about whether their recent loan applications have been accepted, partially rejected, or fully rejected. Households are also asked whether they have successfully reapplied for credit, and whether they have chosen not to apply for credit because they thought they would be rejected. Using these questions, we identify a set of households who report having had no difficulty obtaining their preferred level of credit in the last five years for the 1989 to 2001 surveys, and the last three years for the 1983 survey. To be precise, individuals are coded as not credit constrained if they report that they had not had any loan request turned down or partially rejected, and also that they had not been discouraged from applying for credit in the previous years. In the discussion to follow, these individuals are characterized as not constrained. All other households are characterized as possibly constrained.

Two points are worth emphasizing here for purposes of clarity. First, the second group of households includes individuals who may or may not be credit constrained. This is because some of these households may have secured their preferred level of debt by the time of the survey date but nevertheless accurately report having encountered difficulty in obtaining credit in the past. The uncertain status of these families is not a problem. Instead, as will become apparent, our approach requires only that those families characterized as "not constrained" are accurately classified. Second, and in keeping with the first point, homeowners that report having had difficulty in 
obtaining their preferred level of credit are coded as possibly constrained even though they have already attained owner-occupancy. This is because in the absence of binding credit limits, some of these families might actually have delayed homeownership with the intent of purchasing a more expensive home in the future. Such a strategy could be preferred if it eliminates costly moves into and out of smaller less attractive "starter" homes.

Having stratified families into not constrained $(\mathrm{NotCC}=1)$ and possibly constrained $(\mathrm{NotCC}=0)$ groups, we estimate the propensity for homeownership using just the not constrained households. It is important to recognize, of course, that the NotCC status of a household is likely endogenous. This is because unobserved attributes of the family that influence their propensity to not be credit constrained may well be correlated with their preference for homeownership. Failing to account for such correlation would bias our estimates of the parameters governing a family's preferences for owner-occupied housing. For these reasons, we control for sample selection using a 3-celled bivariate probit model. This model is structured as follows. ${ }^{22}$

We define two unobservable latent indexes that govern the likelihood that a given family is not credit constrained, and also the likelihood that a family prefers to own in the absence of binding credit barriers. These expressions are, respectively,

$$
\mathrm{I}_{\mathrm{NotCC}}=x C+\mathrm{u}_{1}
$$

and

$$
\mathrm{I}_{\mathrm{POwn}}=x b+\mathrm{u}_{2},
$$

where $x$ is a set of household attributes and other control variables, $c$ and $b$ are the corresponding coefficients, and $\mathrm{u}_{1}$ and $\mathrm{u}_{2}$ are error terms that are drawn from a standard bivariate normal distribution with mean zero and covariance $\sigma_{\text {NotCC,POwn }}$. We further assume that a family is not

\footnotetext{
${ }^{22}$ Boyes, Hoffman, and Low [3] estimate a similar three-celled bivariate probit model for the credit card market.
} 
constrained if $\mathrm{I}_{\mathrm{NotCC}}>0$, and possibly constrained if $\mathrm{I}_{\mathrm{NotCC}} \leq 0$. Similarly, in the absence of binding credit barriers, a family prefers to own $(\mathrm{POwn}=1)$ if $\mathrm{I}_{\mathrm{PO} \text { wn }}>0$, and does not prefer to own $(\mathrm{POwn}=0)$ if $\mathrm{I}_{\mathrm{POwn}} \leq 0$.

We stress again that equation (2) is defined only in the absence of binding credit barriers, even among families that currently reside in owner-occupied housing. As a result, POwn is observed only for those families in our sample belonging to the not constrained group. This accounts for why our bivariate probit model has three cells instead of four. The corresponding loglikelihood function for this model is as follows:

$$
\begin{array}{r}
L=\sum\left\{(1-\operatorname{NotCC}) \cdot \log [\mathrm{F}(-x c)]+\text { NotCC } \cdot \text { POwn } \cdot \log \left[\mathrm{G}\left(x b, x c, \sigma_{\text {NotCC,POwn }}\right)\right]\right. \\
\left.+ \text { NotCC } \cdot(1-\mathrm{POwn}) \cdot \log \left[\mathrm{G}\left(-x b, x c,-\sigma_{\text {NotCC,POwn }}\right)\right]\right\},
\end{array}
$$

where $\mathrm{F}(\cdot)$ and $\mathrm{G}(\cdot)$ are the standard unit and bivariate normal distribution functions, respectively, and the other variables are defined as above. It is important to note that maximizing (3) simultaneously estimates $\sigma_{\text {NotCC,own }}$ along with the other model coefficients. This feature of the model controls for unobserved attributes common to the credit constraint and homeownership latent equations and in so doing ensures that our estimate of $b$ is unbiased. Moreover, it should be noted that because we include all of the same covariates in both the credit constraint and homeownership equations - theory does not provide guidance to do otherwise - identification of $\sigma_{\text {NotCC,own }}$ relies on the non-linearity of the bivariate probit function. ${ }^{23}$

\footnotetext{
${ }^{23}$ As is well established (e.g., Maddala, [20]), if the error terms associated with the latent indexes corresponding to POwn and NotCC are uncorrelated, then one could estimate $b$ with a simple probit model over just that portion of the sample for which NotCC $=1$. More generally, however, common omitted variables that influence both the likelihood that NotCC equals 1 and the likelihood that POwn equals 1 would cause estimates of $b$ to suffer from sample selection bias. The likelihood function in (3) controls for that problem. For a more detailed discussion of bivariate probit models with censoring see Maddala [20] or Tunali [31].
} 
Estimates from equation (3) of the propensity for homeownership are presented in Table 3. ${ }^{24}$ To facilitate comparison to Table 2, as before, partial derivatives are reported along with the original model t-ratios. Because of their policy significance, we focus on the race-related measures from both tables. It is important to recognize that the measures from Table 2 provide estimates of racial gaps in homeownership after controlling for household attributes. The measures from Table 3 , in contrast, provide estimates of the residual racial gaps after controlling for both household attributes and the influence of credit barriers.

To facilitate analysis of these measures, in Figures $2 b$ (for African Americans) and $2 c$ (for Hispanics) we plot the minority-white differences in homeownership rates from Table 1, as well as the race-related estimates from Tables 2 and 3 (as described above). In addition, we also plot the difference between the racial gaps in Table 1 and the race-related measures in Table 2: that difference measures the impact of household attributes on racial gaps. Similarly, we also plot the difference between the race-related estimates in Tables 2 and 3: that difference measures the impact of credit barriers on racial gaps.

Several patterns are immediately evident in the figures. First, in each survey year from 1983 to 2001, credit barriers account for no more than 5 percentage points of the white-minority gap in homeownership rates for both blacks and Hispanics. Second, household attributes included in the model account for a much larger share of the racial gap in homeownership in each survey year except for Hispanics in 1983. As of 2001, for example, household attributes account for roughly 15 percentage points of the white-minority homeownership gap for both African Americans and Hispanics.

\footnotetext{
${ }^{24}$ Estimates of the propensity to not be credit constrained, equation (1), are reported in the Appendix.
} 
The unexplained portion of the racial gap in homeownership rates in each year is given by the estimated racial gap after controlling for household attributes and credit barriers, the estimates from Table 3 . In 1983, that portion of the gap was still roughly 12 percentage points for African Americans and 26 percentage points for Hispanics. By 2001, however, those disparities narrowed markedly, to 8.4 and 11.4 percentage points, respectively. It is noteworthy that this narrowing of race-related effects was broadly consistent with changes in the savings behavior of white and minority renters over the survey period. In Figure 3, we display the percentage of renters currently saving to purchase a home based on weighted sample means from the SCF (not probit model results). ${ }^{25}$ Observe that the fraction of African American and Hispanic renters saving for home purchase rose sharply over the 1983 to 2001 period to levels equal to or in excess of those recorded for white renters. In 1983, only 6.8 percent of black renters and 8.5 percent of Hispanic renters were saving to purchase a home, compared with some 12.4 percent of white renters. By 2001, roughly 22 percent of Hispanic renters were saving to buy a home, compared with 16 percent for black renters and 17 percent for white renters.

On balance, these patterns suggest that minority households view homeownership as a far more viable option today than in the past. Nevertheless, from the perspective of ongoing policy efforts to further narrow racial gaps in homeownership, our findings also argue for caution. Household attributes are clearly the dominant driving force in homeownership decisions, and these factors are not easily influenced by policy. Moreover, the unexplained portion of the whiteminority gap in homeownership rates has diminished considerably for both black and Hispanic households, while the influence of credit barriers on racial gaps in homeownership has been limited throughout the study period. This suggests that policy makers will need to look beyond

\footnotetext{
${ }^{25}$ For each survey year, we characterized a family as saving to purchase a home if either their first or second most important reason for saving was for future home purchase.
} 
innovations in mortgage finance if their goal is to substantially reduce racial gaps in homeownership.

\section{Robustness and Residential Location}

As discussed earlier, an important factor that contributes to a household's decision to own versus rent their home is the local quality adjusted house price to rent ratio. Controlling for these factors is important when analyzing the determinants of racial gaps in homeownership. This is because African Americans and Hispanics are disproportionately concentrated in central city locations, and as a result, may face systematically different costs of homeownership relative to the typical suburban white household. We address this concern by drawing on yet another feature of the SCF. For 1992, 1995, and 1998, the public use versions of the SCF allow one to identify the Census region of residence (Northeast, North Central, South, and West), and also the density of development in the individual's neighborhood, a proxy for central city versus suburban location. This latter measure reports whether neighborhood homes are less than 20 feet apart, 20 to 100 feet apart, or more than 100 feet apart. For 1992, 1995, and 1998, we re-estimated all of the models and simulations including these variables to proxy in part for the local cost of homeownership relative to renting. ${ }^{26}$

Our revised estimates of the partial derivatives for the housing tenure covariates in the probit and bivariate probit specifications are presented in the Appendix, while Figures 4a, 4b, and $4 \mathrm{c}$ provide updated plots of the patterns in Figures 2a, 2b, and 2c, respectively. Three points are important to take note of in these plots. First, the patterns in Figure 4a continue to suggest that the

\footnotetext{
${ }^{26}$ In principle, neighborhood density of development could be endogenous to housing tenure preferences. For example, if central city locations offer superior rental opportunities, families with weaker than average tastes for homeownership will be drawn to such locations. Although we cannot rule out this possibility, it seems unlikely that this would substantially bias our estimates.
} 
increase in homeownership in the 1990s was driven primarily by changes in the sociodemographic attributes of the population, not changes in market conditions. Second, in 1998, household socio-demographic attributes and location account for all but 8.3 percentage points of the white-black homeownership gap, and all but 10.5 percentage points of the white-Hispanic gap, roughly two-thirds of the racial gaps in that year. Of the remaining third, credit barriers account for no more than 5 percentage points for African Americans, while for Hispanics, the influence of credit barriers is largely eliminated. Overall, these findings suggest that the primary conclusions drawn from our analysis are robust to controls for region of the country and for neighborhood density of development.

\section{Conclusion}

After stagnating during the 1980s, U.S. homeownership rates rose sharply during the 1990s to a high of 67.5 percent in 2001. At the same time, substantial gaps in homeownership rates between white and minority households persisted, averaging roughly 26 percentage points for blacks and 28 percentage points for Hispanics over the 1983 to 2001 period. In the past decade, these events have coincided with a boom in the national economy, declining interest rates, the aging of the baby boomers, and other demographic shifts. The increase in homeownership in the 1990s also coincided with federal housing policy and mortgage/housing industry initiatives designed to expand access to mortgage credit and to boost homeownership, especially among lower income and minority households.

This paper uses data from the Survey of Consumer Finances to analyze the determinants of trends in aggregate homeownership rates and long-standing racial gaps in homeownership. Results indicate that changes in population socio-demographic attributes account for most of the 
increase in homeownership between 1989 and 2001. This implies that innovations in mortgage finance and declining interest rates, while clearly beneficial to prospective homeowners, likely were not the primary drivers of the rise in homeownership during the 1990s.

Our findings also demonstrate that by the end of the 1990s, household socio-demographic attributes and location accounted for all but 8.3 percentage points of the white-black gap in homeownership, and all but 10.5 percentage points of the white-Hispanic gap. Moreover, for each survey year from 1983 to 2001, credit barriers accounted for no more than 5 percentage points of the white-black and white-Hispanic differences in homeownership rates. These findings suggest that policy makers will likely need to look beyond innovations in mortgage finance if their goal is to substantially expand homeownership and also to reduce racial gaps in owner-occupancy rates.

In light of the findings in this paper, two recent developments since 2001 warrant mention. First, homeownership rates continue to climb among all groups of households but racial gaps remain high. Based on the Consumer Population Survey (CPS), in the second quarter of 2004, homeownership rates reached 69.2 percent for the nation, 76.2 percent for non-Hispanic whites, 49.7 percent for African Americans, and 47.4 percent for Hispanics. ${ }^{27}$ Because the SCF data extend only to 2001, we cannot be certain as to what has prompted these changes. Second, recently enacted policies have begun to provide direct subsidies to lower-income homebuyers. For example, the American Dream Downpayment Act, signed into law in 2003, provides low-

\footnotetext{
${ }^{27}$ For details, see http://www.census.gov/hhes/www/housing/hvs/q204tab5.html at the Census Department housing data website. See also http://www.census.gov/hhes/www/housing/hvs/q204prss.pdf where additional details are provided in a Census department press release.
} 
income homebuyers with tax credits that reduce the cost of homeownership. ${ }^{28}$ The impact of this and related policy initiatives remains a topic for future research.

${ }^{28}$ See also the Whitehouse website, http://www.whitehouse.gov/news/releases/2004/09/20040902-5.html, for further discussion of recent housing policy initiatives. 


\section{References}

[1] H. Aaron, Income Taxes and Housing, American Economic Review, 60 (1970) 789-806.

[2] Bank of America. 1998. Bank of America Launches First Ever Widely Available Zero Down Payment Mortgage. Bank of America news release, March 2.

[3] W. Boyes, D. Hoffman, and S. Low. An econometric analysis of the bank credit scoring problem, Journal of Econometrics 40 (1989) 3-14.

[4] G. Canner, D. Smith. Home mortgage disclosure act: expanded data on residential lending. Federal Reserve Bulletin (1991) 859-81.

[5] E. Coulson, Why are Hispanic- and Asian-American homeownership rates so low? Immigration and other factors, Journal of Urban Economics, 45 (1999) 209-227.

[6] D. Cox, T. Jappelli. The effect of borrowing constraints on consumer liabilities. Journal of Money, Credit and Banking 25 (1993) 197-213.

[7] J. Duca, S. Rosenthal. Borrowing constraints, household debt, and racial discrimination in loan markets, Journal of Financial Intermediation 3 (1993) 77-103.

[8] J. Duca, S. Rosenthal. Borrowing constraints and access to owner-occupied housing, Regional Science and Urban Economics 24 (1994) 301-322.

[9] S. Gabriel, G. Painter, Paths to Homeownership: An Analysis of the residential location and homeownership choices of black households, Journal of Real Estate Finance and Economics 27(2003).

[10] S. Gabriel, S. Rosenthal, Credit rationing, race, and the mortgage market, Journal of Urban Economics, 29 (1991) 371-379.

[11] J Gyourko, P.Linneman, An analysis of the changing influences on traditional household ownership patterns, Journal of Urban Economics 39 (1996) 318-341.

[12] D. Haurin, S. Rosenthal, C. Herbert, and M. Duda, 2002. "A Review of the Literature on Homeownership Gaps Among Low-Income and Minority Borrowers and Neighborhoods," prepared for the Department of Housing and Urban Development (HUD).

[13] V. Henderson, Y.Ioannides, 1983. "A model of housing tenure choice”, The American Economic Review, (73) 98-113.

[14] Y. Ioannides and S. Rosenthal, 1994. "Estimating the consumption and investment demands for housing and their effect on housing tenure status", The Review of Economics and Statistics, (76) 127-141. 
[15] T. Jappelli, Who is credit constrained in the U.S? Quarterly Journal of Economics 105 (1990) 219-234.

[16] A. Kennickell, "Revisions to the SCF Weighting Methodology: Accounting for Race/Ethnicity and Homeownership," Federal Reserve Board working paper, January 1999.

[17] A. Kennickell, "Multiple Imputation in the Survey of Consumer Finances," Federal Reserve Board working paper, September 1998.

[18] P. Linneman, S. Wachter, The impacts of borrowing constraints on homeownership, AREUEA Journal 17 (1989) 389-402.

[19] D. Laidler, Income tax incentives for owner-occupied housing, in: The taxation of income from capital, A.C. Harberger and M.J. Bailey (eds.), Brookings Institution, Washington, DC. 1969, pp. 50-76.

[20] G. Maddala, Limited-Dependent and Qualitative Variables in Econometrics, Cambridge University Press, New York 1983.

[21] A. Munnell, G. Tootell, L. Browne and J. McEneaney, Mortgage lending in Boston: Interpreting the HMDA data, American Economic Review 86 (1996) 25-53.

[22] G. Painter, S. Gabriel, D. Myers, The decision to own: The impact of race, ethnicity, and immigrant status, Journal of Urban Economics 49 (2001) 150-167.

[23] B. Rehm, ABA Rebuts Bias Charge in Fed Study on Lending American Banker, (October 15, 1991) $1 \& 19$.

[24] B. Rehm, Data on Bias in Lending Sparks Demands for Action, American Banker, (October 22, 1991) $1 \& 9$.

[25] H. Rosen, Housing decisions and the U.S. income tax: An econometric analysis, Journal of Public Economics 11(1979) 1-24.

[26] H. Rosen, Housing subsidies: Effects on housing decisions, efficiency, and equity, in: A. Auerback and M. Feldstein (Eds.) Handbook of Public Economics, North Holland, Amsterdam, 1985

[27] S. Rosenthal, A residence time model of housing markets, Journal of Public Economics 36 (1988) 87-109.

[28] S. Rosenthal, Eliminating credit barriers to increase homeownership: How far can we go? In: Low-Income Homeownership: Examining the Unexamined Goal, E. Belsky and N. Retsina (Eds.) Brookings Institution Press, Washington D.C., 2002. 
[29] S. Ross, J. Yinger, The Color of Credit: Mortgage Lending Discrimination, Research Methodology, and Fair Lending Enforcement, MIT Press, Cambridge 2002.

[30] Turner, Margery Austin, Fred Freiberg, Erin Godfrey, Carla Herbig, Diane K. Levy, and Robin R. Smith, "All Other Things Being Equal: A Paired Testing Study of Mortgage Lending Institutions," U.S. Department of Housing and Urban Development, Office of Fair Housing and Equal Opportunity," http://www.huduser.org/Publications/PDF/aotbe.pdf , April 2002.

[31] I. Tunali, A general structure for models of double-selection and an application to a joint migration/earnings process with remigration, Research in Labor Economics 8 (1986) 235-282.

[32] S. Wachter, I. Megbolugbe, Racial and ethnic disparities in homeownership, Housing Policy Debate, 3 (1992) 333-370.

[33] P. Zorn, Mobility-tenure decisions and financial credit: Do mortgage qualification requirements constrain home ownership? AREUEA Journal 17 (1989) 1-16. 
Table 1

Homeownership Rates ${ }^{a}$

\begin{tabular}{rcccccc}
\hline & 1983 & 1989 & 1992 & 1995 & 1998 & 2001 \\
\hline All Households & 0.635 & 0.639 & 0.640 & 0.647 & 0.662 & 0.675 \\
White Households & 0.680 & 0.705 & 0.703 & 0.705 & 0.717 & 0.740 \\
Black Households & 0.448 & 0.422 & 0.436 & 0.428 & 0.459 & 0.474 \\
Hispanic Households & 0.316 & 0.418 & 0.397 & 0.430 & 0.440 & 0.443 \\
\hline
\end{tabular}

${ }^{a}$ All estimates are based on data from different years of the Survey of Consumer Finances and are weighted to be representative of the United States. Excludes families with total family earned income (in \$2001) above $\$ 1,000,000$, or missing. 
Table 2: Homeownership Propensity Estimated Over All Households

Without Controlling for Borrowing Constraints

(Partial Dervatives Are Reported) ${ }^{a}$

\begin{tabular}{|c|c|c|c|c|c|c|}
\hline & 1983 & 1989 & 1992 & 1995 & 1998 & 2001 \\
\hline \multirow[t]{2}{*}{ Some college } & 0.0075 & 0.0379 & 0.0445 & 0.0267 & 0.0271 & -0.0181 \\
\hline & $(0.38)$ & $(1.56)$ & $(2.21)$ & $(1.40)$ & (1.48) & $(-1.02)$ \\
\hline \multirow[t]{2}{*}{ College degree } & 0.0172 & 0.0224 & 0.0149 & 0.0156 & 0.0165 & 0.0342 \\
\hline & $(0.89)$ & $(0.91)$ & $(0.74)$ & $(0.80)$ & $(0.90)$ & (1.87) \\
\hline \multirow[t]{2}{*}{ Married } & 0.1634 & 0.2408 & 0.1852 & 0.1468 & 0.2206 & 0.1580 \\
\hline & $(6.74)$ & $(7.54)$ & $(6.91)$ & $(5.70)$ & $(9.34)$ & $(6.72)$ \\
\hline \multirow[t]{2}{*}{ Single Male } & -0.0091 & 0.0185 & -0.0430 & -0.0191 & 0.0035 & 0.0208 \\
\hline & $(-0.38)$ & $(0.67)$ & $(-1.79)$ & $(-0.84)$ & $(0.17)$ & $(1.05)$ \\
\hline \multirow[t]{2}{*}{ Divorced } & -0.0080 & 0.0944 & 0.0184 & 0.0375 & 0.0551 & 0.0584 \\
\hline & $(-0.33)$ & $(3.41)$ & $(0.72)$ & $(1.54)$ & $(2.50)$ & $(2.82)$ \\
\hline \multirow[t]{2}{*}{ Age X Dummy for Under 35} & 0.0096 & 0.0063 & 0.0073 & 0.0039 & 0.0051 & 0.0085 \\
\hline & $(5.11)$ & $(2.63)$ & $(3.38)$ & $(1.86)$ & $(2.71)$ & $(4.51)$ \\
\hline \multirow[t]{2}{*}{ Age X Dummy for Between 35 and 55} & 0.0114 & 0.0082 & 0.0099 & 0.0070 & 0.0073 & 0.0096 \\
\hline & $(8.70)$ & $(4.93)$ & $(6.61)$ & $(4.79)$ & $(5.74)$ & $(7.59)$ \\
\hline \multirow[t]{2}{*}{ Age X Dummy for Over 55} & 0.0101 & 0.0090 & 0.0091 & 0.0080 & 0.0078 & 0.0089 \\
\hline & (11.51) & $(8.15)$ & (9.14) & $(8.11)$ & $(8.95)$ & $(10.07)$ \\
\hline \multirow[t]{2}{*}{ Household size } & 0.0321 & 0.0336 & 0.0105 & 0.0261 & 0.0185 & 0.0234 \\
\hline & $(5.04)$ & $(4.78)$ & $(1.53)$ & (3.97) & $(2.86)$ & (3.81) \\
\hline \multirow[t]{2}{*}{ African American ${ }^{b}$} & -0.1414 & -0.1116 & -0.1278 & -0.1361 & -0.1003 & -0.1172 \\
\hline & $(-6.24)$ & $(-3.94)$ & $(-4.98)$ & $(-5.62)$ & $(-4.18)$ & $(-5.27)$ \\
\hline \multirow[t]{2}{*}{ Hispanic $^{b}$} & -0.2932 & -0.1877 & -0.1821 & -0.1887 & -0.1726 & -0.1658 \\
\hline & $(-6.73)$ & $(-4.79)$ & $(-5.53)$ & $(-5.19)$ & $(-5.71)$ & $(-5.97)$ \\
\hline \multirow{2}{*}{ Other Race (including Asian) ${ }^{b}$} & -0.1078 & -0.0485 & -0.1026 & -0.1684 & -0.1777 & -0.1492 \\
\hline & $(-1.64)$ & $(-1.10)$ & $(-2.61)$ & $(-3.89)$ & $(-4.02)$ & $(-3.18)$ \\
\hline \multirow[t]{2}{*}{ Head in bad health } & 0.0055 & -0.0661 & -0.0215 & -0.0931 & -0.1042 & -0.0931 \\
\hline & $(0.19)$ & $(-1.87)$ & $(-0.65)$ & $(-2.65)$ & $(-2.93)$ & $(-3.01)$ \\
\hline \multirow[t]{2}{*}{ Spouse in bad health } & -0.1326 & -0.0753 & -0.0874 & -0.0612 & -0.1135 & -0.0256 \\
\hline & $(-3.17)$ & $(-1.27)$ & $(-1.56)$ & $(-1.16)$ & $(-2.35)$ & $(-0.55)$ \\
\hline \multirow[t]{2}{*}{ Household earned income (\$2001) } & 0.0026 & 0.0036 & 0.0028 & 0.0026 & 0.0031 & 0.0025 \\
\hline & $(3.47)$ & $(5.37)$ & $(6.26)$ & $(5.51)$ & $(8.00)$ & $(8.06)$ \\
\hline \multirow[t]{2}{*}{ Household earned inc squared (\$2001) } & $1.36 \mathrm{E}-06$ & $-4.66 \mathrm{E}-06$ & $-3.33 \mathrm{E}-06$ & $-3.01 \mathrm{E}-06$ & $-3.11 \mathrm{E}-06$ & $-2.67 \mathrm{E}-06$ \\
\hline & $(0.18)$ & $(-4.94)$ & $(-4.91)$ & $(-6.07)$ & $(-7.61)$ & $(-7.48)$ \\
\hline \multirow{2}{*}{ Head works full-time } & 0.0694 & 0.0653 & 0.1061 & 0.1294 & 0.0400 & 0.0375 \\
\hline & $(3.45)$ & (1.99) & $(4.20)$ & $(5.14)$ & $(1.65)$ & $(1.62)$ \\
\hline \multirow[t]{2}{*}{ Spouse works full-time } & 0.0064 & 0.0201 & 0.0094 & 0.0657 & 0.0234 & 0.0650 \\
\hline & $(0.30)$ & $(0.70)$ & $(0.40)$ & $(3.03)$ & $(1.13)$ & (3.28) \\
\hline \multirow[t]{2}{*}{ Spouse works part-time } & 0.0698 & 0.0937 & 0.0253 & 0.0424 & 0.0295 & 0.0754 \\
\hline & $(2.22)$ & (2.49) & $(0.82)$ & $(1.43)$ & $(0.90)$ & $(2.57)$ \\
\hline \multirow[t]{2}{*}{ Head's \# full-time jobs lasting > 1 year } & -0.0093 & -0.0085 & -0.0151 & -0.0151 & -0.0078 & -0.0065 \\
\hline & $(-2.78)$ & $(-1.87)$ & $(-4.09)$ & $(-4.27)$ & $(-2.63)$ & $(-2.23)$ \\
\hline \multirow[t]{2}{*}{ Constant } & -0.6112 & -0.5944 & -0.5145 & -0.4631 & -0.4596 & -0.5332 \\
\hline & $(-10.04)$ & $(-7.59)$ & $(-7.45)$ & $(-6.75)$ & $(-7.30)$ & $(-8.43)$ \\
\hline Number of obs & 3,665 & 3,112 & 3,869 & 4,256 & 4,236 & 4,353 \\
\hline Log likelihood & $-1,855.1$ & $-1,467.0$ & $-1,937.3$ & $-2,127.7$ & $-2,009.7$ & $-2,076.3$ \\
\hline
\end{tabular}

${ }^{a}$ Partial derivatives were calculated for each observation and then averaged over the sample applying sampling weights to ensure results are representative of the United States (see the text for details). For a given 1-0 slope variable, $X_{1-0}$, derivatives were obtained by calculating the unconditional probability of owning first with $X_{1-0}$ set equal to 1 , next with $X_{1-0}$ set equal to 0 , and then differencing the results. For all other variables derivatives were formed as $f(\mathrm{x} b) b$, where $f$ is the probability density function for the standard normal and $b$ is the probit model coefficient. The t-ratios in parentheses are those for the untransformed model coefficients.

Observations with total household earned income above $\$ 1,000,000$ (in 2001 dollars) or missing were excluded from each sample.

${ }^{b}$ Omitted category is White. 
Table 3: Homeownership Propensity Estimated Over Not Credit Constrained Households Controlling for Sample Selection (Partial Dervatives Are Reported) ${ }^{a}$

\begin{tabular}{|c|c|c|c|c|c|c|}
\hline & 1983 & 1989 & 1992 & 1995 & 1998 & 2001 \\
\hline \multirow[t]{2}{*}{ Some college } & 0.0176 & 0.0349 & 0.0378 & 0.0501 & 0.0205 & -0.0090 \\
\hline & $(0.82)$ & $(1.33)$ & $(1.78)$ & $(2.42)$ & $(1.10)$ & $(-0.50)$ \\
\hline \multirow[t]{2}{*}{ College degree } & 0.0077 & -0.0103 & 0.0041 & -0.0021 & 0.0136 & 0.0152 \\
\hline & $(0.38)$ & $(-0.40)$ & $(0.20)$ & $(-0.11)$ & $(0.73)$ & $(0.87)$ \\
\hline \multirow[t]{2}{*}{ Married } & 0.1296 & 0.1649 & 0.1599 & 0.1279 & 0.1754 & 0.1312 \\
\hline & $(4.87)$ & $(5.14)$ & $(5.63)$ & $(4.79)$ & $(7.28)$ & $(5.56)$ \\
\hline \multirow[t]{2}{*}{ Single Male } & -0.0134 & 0.0121 & -0.0282 & 0.0178 & 0.0005 & 0.0164 \\
\hline & $(-0.52)$ & $(0.41)$ & $(-1.11)$ & $(0.74)$ & $(0.03)$ & $(0.85)$ \\
\hline \multirow[t]{2}{*}{ Divorced } & -0.0212 & 0.0687 & 0.0522 & 0.0356 & 0.0593 & 0.0612 \\
\hline & $(-0.80)$ & $(2.36)$ & $(1.98)$ & $(1.39)$ & $(2.70)$ & $(3.04)$ \\
\hline \multirow[t]{2}{*}{ Age X Dummy for Under 35} & 0.0031 & 0.0016 & 0.0021 & 0.0006 & 0.0012 & 0.0010 \\
\hline & $(1.55)$ & $(0.65)$ & $(0.96)$ & $(0.26)$ & $(0.59)$ & $(0.51)$ \\
\hline \multirow[t]{2}{*}{ Age X Dummy for Between 35 and 55} & 0.0055 & 0.0036 & 0.0050 & 0.0027 & 0.0032 & 0.0029 \\
\hline & $(3.84)$ & $(1.97)$ & $(3.22)$ & $(1.73)$ & $(2.29)$ & $(2.27)$ \\
\hline \multirow[t]{2}{*}{ Age X Dummy for Over 55} & 0.0051 & 0.0041 & 0.0043 & 0.0041 & 0.0036 & 0.0030 \\
\hline & $(4.92)$ & $(3.33)$ & $(4.09)$ & (3.69) & $(3.71)$ & $(3.25)$ \\
\hline \multirow[t]{2}{*}{ Household size } & 0.0337 & 0.0330 & 0.0177 & 0.0289 & 0.0240 & 0.0220 \\
\hline & $(4.62)$ & (3.99) & $(2.34)$ & $(3.88)$ & $(3.18)$ & $(3.20)$ \\
\hline \multirow[t]{2}{*}{ African American ${ }^{b}$} & -0.1204 & -0.0655 & -0.0855 & -0.0719 & -0.0394 & -0.0841 \\
\hline & $(-4.20)$ & $(-1.94)$ & $(-2.75)$ & $(-2.38)$ & $(-1.43)$ & $(-3.32)$ \\
\hline \multirow[t]{2}{*}{ Hispanic $^{b}$} & -0.2609 & -0.1344 & -0.1568 & -0.1689 & -0.1431 & -0.1139 \\
\hline & $(-5.01)$ & $(-2.72)$ & $(-3.72)$ & $(-3.92)$ & $(-4.21)$ & $(-3.86)$ \\
\hline \multirow[t]{2}{*}{ Other Race (including Asian) ${ }^{b}$} & -0.1545 & 0.0083 & -0.1129 & -0.1016 & -0.1797 & -0.0935 \\
\hline & $(-2.00)$ & $(0.16)$ & $(-2.71)$ & $(-1.96)$ & $(-3.78)$ & $(-1.85)$ \\
\hline \multirow{2}{*}{ Head in bad health } & -0.0316 & -0.0304 & -0.0331 & -0.0979 & -0.0603 & -0.0944 \\
\hline & $(-1.07)$ & $(-0.81)$ & $(-1.00)$ & $(-2.62)$ & $(-1.74)$ & $(-3.05)$ \\
\hline \multirow[t]{2}{*}{ Spouse in bad health } & -0.1106 & -0.1149 & -0.1103 & -0.0810 & -0.0958 & 0.0158 \\
\hline & $(-2.46)$ & $(-1.86)$ & $(-1.85)$ & $(-1.40)$ & $(-1.75)$ & $(0.33)$ \\
\hline \multirow[t]{2}{*}{ Household earned income (\$2001) } & 0.0020 & 0.0029 & 0.0022 & 0.0018 & 0.0021 & 0.0014 \\
\hline & (2.69) & (4.02) & (4.43) & (3.62) & (5.04) & (4.88) \\
\hline \multirow[t]{2}{*}{ Household earned inc squared (\$2001) } & $1.29 \mathrm{E}-06$ & $-2.91 \mathrm{E}-06$ & $-2.40 \mathrm{E}-06$ & $-1.90 \mathrm{E}-06$ & $-2.18 \mathrm{E}-06$ & $-1.45 \mathrm{E}-06$ \\
\hline & $(0.18)$ & $(-3.53)$ & $(-3.83)$ & $(-3.98)$ & $(-5.17)$ & $(-4.67)$ \\
\hline \multirow{2}{*}{ Head works full-time } & 0.0213 & 0.0401 & 0.0609 & 0.0847 & 0.0533 & 0.0030 \\
\hline & $(0.97)$ & $(1.15)$ & $(2.16)$ & $(2.96)$ & $(1.92)$ & $(0.13)$ \\
\hline \multirow[t]{2}{*}{ Spouse works full-time } & 0.0163 & -0.0006 & -0.0072 & 0.0506 & 0.0087 & 0.0545 \\
\hline & $(0.71)$ & $(-0.02)$ & $(-0.28)$ & $(2.09)$ & $(0.39)$ & $(2.75)$ \\
\hline \multirow[t]{2}{*}{ Spouse works part-time } & 0.0623 & 0.0671 & -0.0083 & 0.0234 & 0.0499 & 0.0623 \\
\hline & $(1.87)$ & $(1.76)$ & $(-0.25)$ & $(0.74)$ & $(1.48)$ & $(2.16)$ \\
\hline \multirow[t]{2}{*}{ Head's \# full-time jobs lasting > 1 year } & -0.0043 & -0.0066 & -0.0065 & -0.0044 & -0.0074 & 0.0011 \\
\hline & $(-1.17)$ & $(-1.36)$ & $(-1.56)$ & $(-1.16)$ & $(-1.89)$ & $(0.39)$ \\
\hline \multirow[t]{2}{*}{ Constant } & -0.2318 & -0.2051 & -0.1698 & -0.1713 & -0.1582 & -0.0876 \\
\hline & $(-3.14)$ & $(-2.32)$ & $(-2.27)$ & $(-2.17)$ & $(-2.20)$ & $(-1.32)$ \\
\hline \multirow[t]{2}{*}{ Rho } & -0.6517 & -0.9394 & -0.7179 & -0.7287 & -0.7134 & -0.7622 \\
\hline & $(-5.72)$ & $(-12.55)$ & $(-7.43)$ & $(-8.58)$ & $(-6.99)$ & $(-8.52)$ \\
\hline Uncensored obs (not credit constrained) & 2,937 & 2,516 & 2,915 & 3,244 & 3,197 & 3,356 \\
\hline Censored obs (possibly constrained) & 728 & 596 & 954 & 1,012 & 1,039 & 997 \\
\hline Log likelihood & -0.7996 & -0.8075 & -0.8355 & -0.8322 & -0.8074 & -0.8019 \\
\hline
\end{tabular}

${ }^{a}$ Partial derivatives were calculated for each observation and then averaged over the sample applying sampling weights to ensure results are representative of the United States (see the text for details). For a given 1-0 slope variable, $X_{1-0}$, derivatives were obtained by calculating the unconditional probability of owning first with $X_{1-0}$ set equal to 1 , next with $X_{1-0}$ set equal to 0 , and then differencing the results. For all other variables derivatives were formed as $f(x b) b$, where $f$ is the probability distribution function for the standard normal and $b$ is the probit model coefficient. The t-ratios in parentheses are those for the untransformed model coefficients.

Observations with total household earned income above \$1,000,000 (in 2001 dollars) or missing were excluded from each sample.

${ }^{b}$ Omitted category is White. 

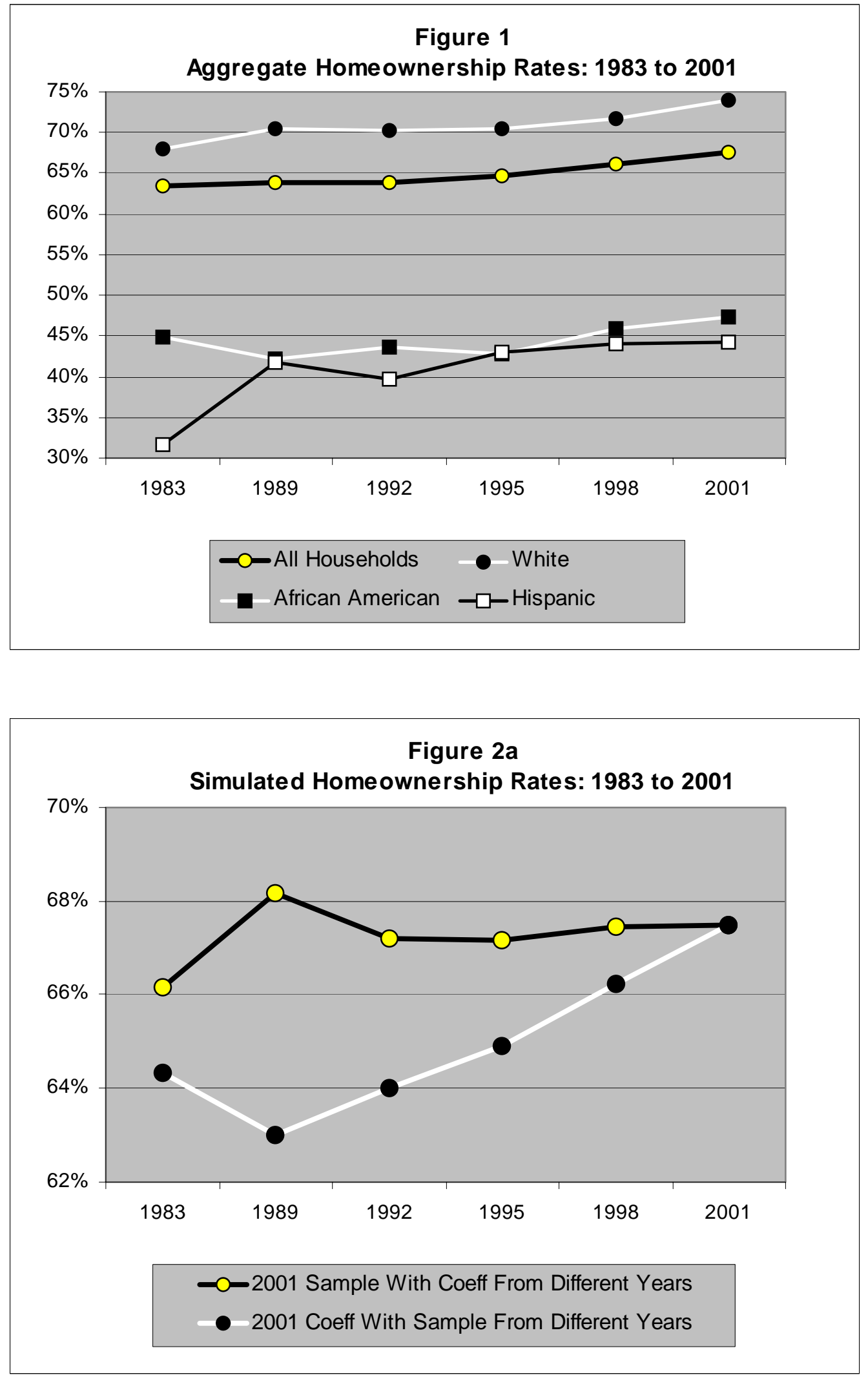

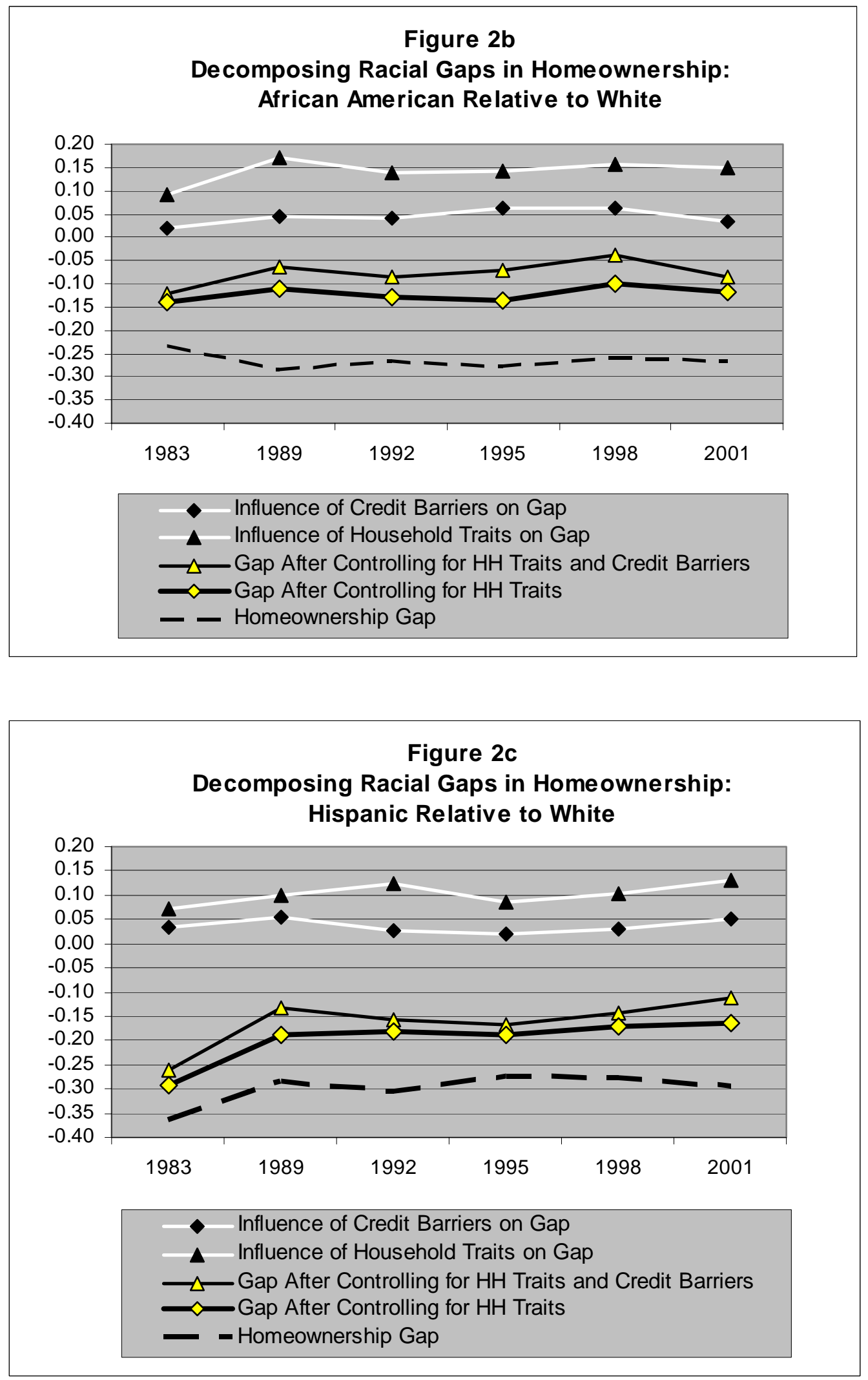

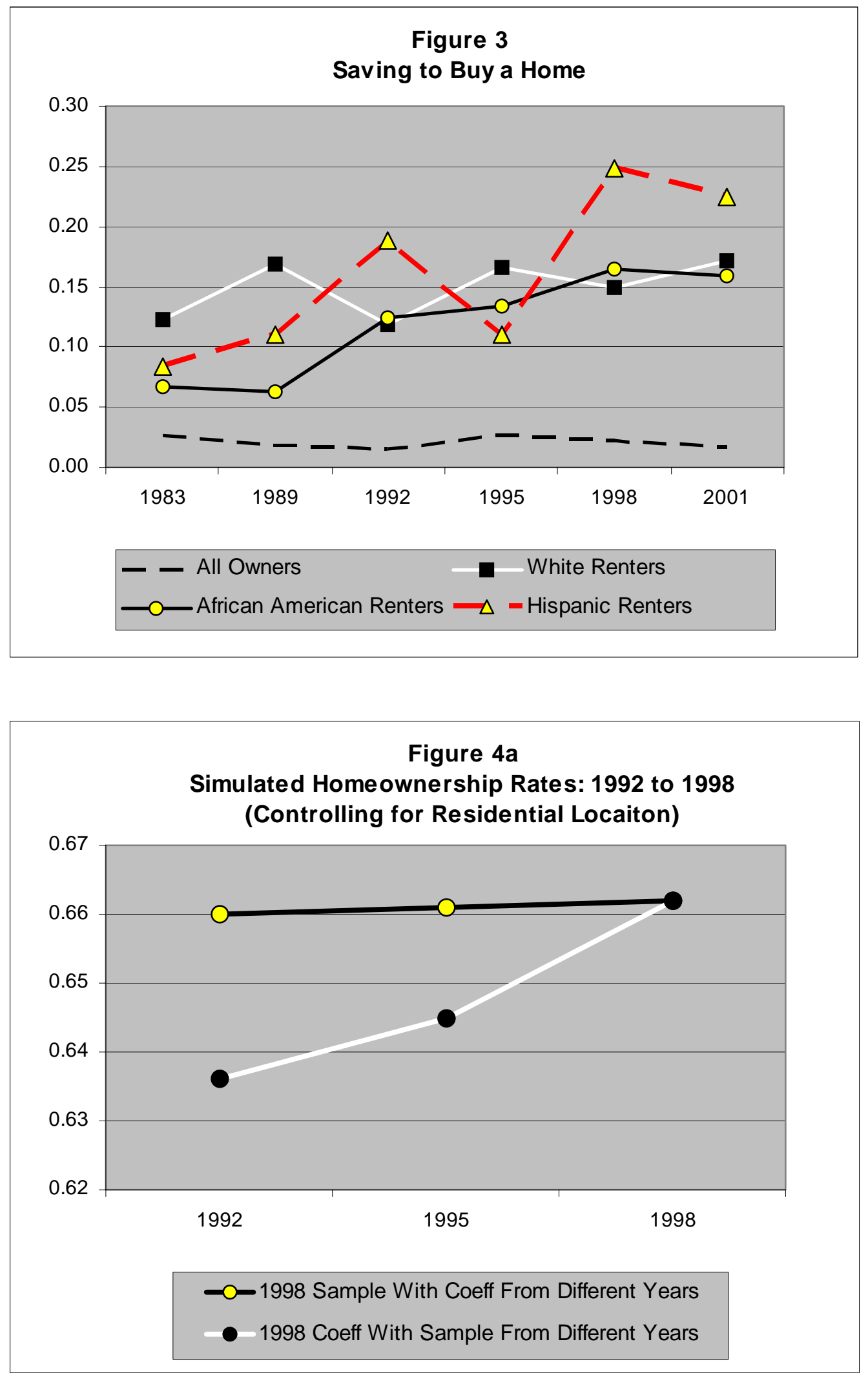

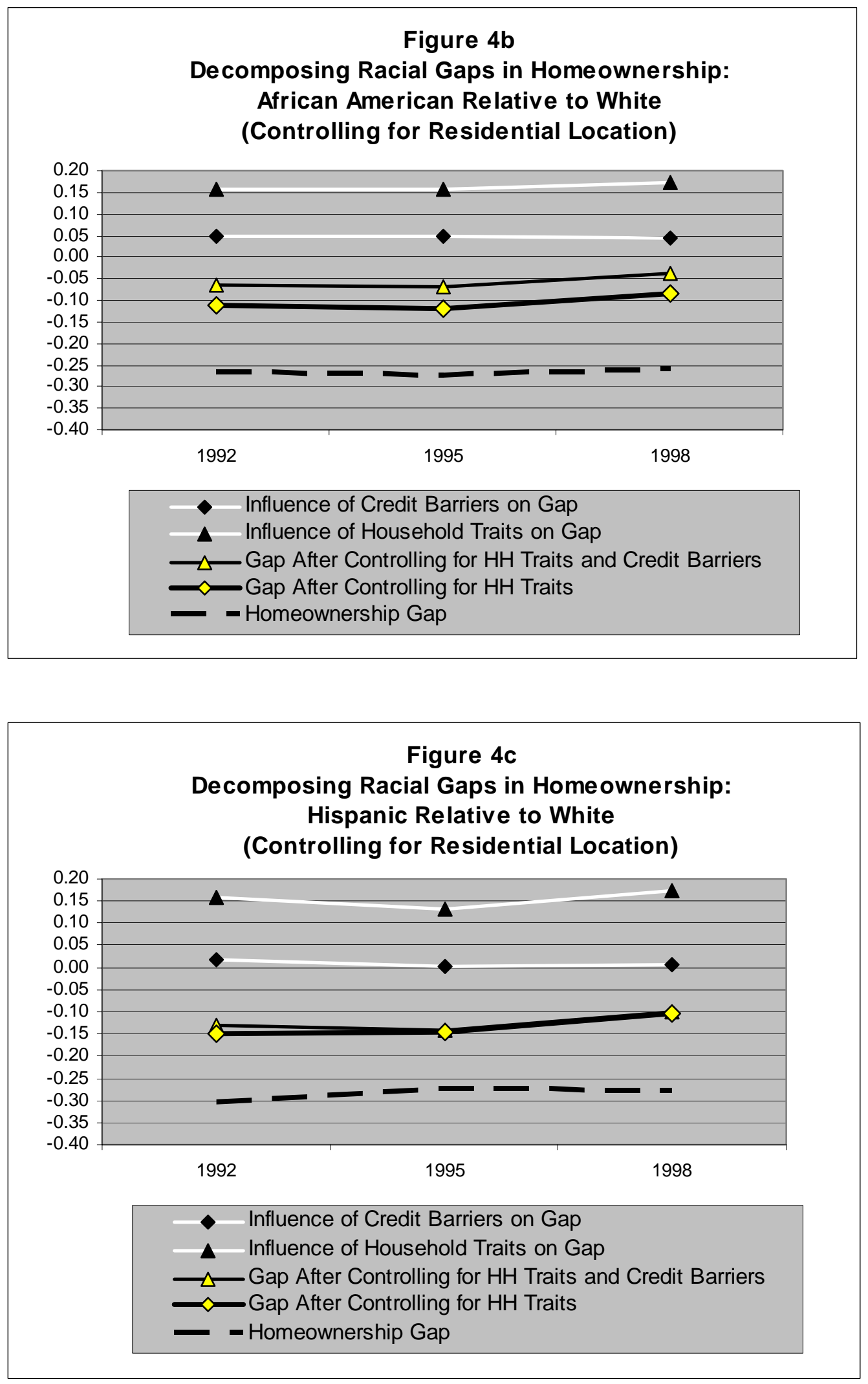


\section{Appendix: Supplemental Tables}

Table A-1: Sample Variable Mean Values From Regression Models (All values are weighted to be representative of the United States)

\begin{tabular}{|c|c|c|c|c|c|c|}
\hline & 1983 & 1989 & 1992 & 1995 & 1998 & 2001 \\
\hline Homeownership Rate & 0.635 & 0.639 & 0.640 & 0.647 & 0.662 & 0.675 \\
\hline Percent Not Credit Constrained & 0.797 & 0.761 & 0.722 & 0.714 & 0.716 & 0.730 \\
\hline Less Than College & 0.594 & 0.566 & 0.505 & 0.501 & 0.482 & 0.478 \\
\hline Some college & 0.176 & 0.201 & 0.212 & 0.236 & 0.238 & 0.227 \\
\hline College degree & 0.230 & 0.234 & 0.283 & 0.263 & 0.281 & 0.296 \\
\hline Married & 0.607 & 0.552 & 0.540 & 0.525 & 0.522 & 0.528 \\
\hline Single Male & 0.130 & 0.166 & 0.182 & 0.189 & 0.204 & 0.206 \\
\hline Divorced & 0.117 & 0.123 & 0.119 & 0.128 & 0.126 & 0.133 \\
\hline Age X Dummy for Under 35 & 9.34 & 8.70 & 8.26 & 7.82 & 7.26 & 6.93 \\
\hline Age X Dummy for Between 35 and 55 & 11.30 & 12.02 & 12.96 & 13.98 & 14.22 & 14.64 \\
\hline Age X Dummy for Over 55 & 26.11 & 27.24 & 27.25 & 26.65 & 27.25 & 27.39 \\
\hline Household size & 2.758 & 2.728 & 2.615 & 2.577 & 2.592 & 2.565 \\
\hline African American & 0.129 & 0.128 & 0.127 & 0.128 & 0.118 & 0.130 \\
\hline Hispanic & 0.037 & 0.080 & 0.075 & 0.057 & 0.071 & 0.080 \\
\hline Other Race (including Asian) & 0.012 & 0.044 & 0.046 & 0.040 & 0.033 & 0.028 \\
\hline Head in bad health & 0.071 & 0.077 & 0.070 & 0.065 & 0.052 & 0.058 \\
\hline Spouse in bad health & 0.032 & 0.028 & 0.023 & 0.023 & 0.021 & 0.026 \\
\hline Household Earned Income (\$2001) & 30.01 & 26.00 & 28.70 & 32.36 & 36.76 & 44.17 \\
\hline Household earned inc squared (\$2001) & 2,096 & 2,139 & 2,510 & 3,284 & 3,840 & 6,103 \\
\hline Head works full-time & 0.629 & 0.615 & 0.594 & 0.605 & 0.634 & 0.649 \\
\hline Spouse works full-time & 0.254 & 0.249 & 0.252 & 0.270 & 0.283 & 0.297 \\
\hline Spouse works part-time & 0.062 & 0.087 & 0.092 & 0.086 & 0.075 & 0.078 \\
\hline Head's \# full-time jobs lasting > 1 year & 3.013 & 2.200 & 2.028 & 2.067 & 2.303 & 2.341 \\
\hline Homes on block $<20 \mathrm{ft}$ apart or missing ${ }^{\mathrm{a}}$ & & & 0.503 & 0.496 & 0.490 & \\
\hline Homes on block 20 to 100 feet apart ${ }^{\mathrm{a}}$ & & & 0.366 & 0.365 & 0.376 & \\
\hline Homes on block $>100$ feet apart ${ }^{\mathrm{a}}$ & & & 0.132 & 0.139 & 0.134 & \\
\hline Northeast $t^{\mathrm{a}}$ & & & 0.202 & 0.198 & 0.193 & \\
\hline Northcentral $^{\mathrm{a}}$ & & & 0.243 & 0.240 & 0.237 & \\
\hline South $^{\mathrm{a}}$ & & & 0.346 & 0.351 & 0.358 & \\
\hline West $^{\mathrm{a}}$ & & & 0.208 & 0.212 & 0.212 & \\
\hline
\end{tabular}

${ }^{a}$ Neighborhood density is not available in 1983, 1989, and 2001. Census region is not available in 1989 and 2001. Both variables are excluded from the 1983, 1989 and 2001 regressions. 
Table A-2: Bivariate Probit Model Estimates of the Not Constrained Equation Corresponding to Table $3^{a}$

\begin{tabular}{|c|c|c|c|c|c|c|}
\hline & 1983 & 1989 & 1992 & 1995 & 1998 & 2001 \\
\hline \multirow[t]{2}{*}{ Some college } & -0.0518 & -0.0241 & -0.0636 & -0.0497 & -0.0679 & -0.1503 \\
\hline & $(-0.74)$ & $(-0.25)$ & $(-0.89)$ & $(-0.77)$ & $(-1.03)$ & $(-2.34)$ \\
\hline \multirow[t]{2}{*}{ College degree } & 0.0639 & 0.1208 & 0.0111 & 0.1103 & 0.1084 & 0.1958 \\
\hline & $(0.89)$ & $(1.26)$ & $(0.16)$ & $(1.61)$ & $(1.60)$ & $(2.81)$ \\
\hline \multirow[t]{2}{*}{ Married } & 0.3712 & 0.0679 & 0.0594 & 0.0526 & 0.1240 & 0.1891 \\
\hline & (4.12) & $(0.55)$ & $(0.63)$ & $(0.57)$ & $(1.42)$ & $(2.19)$ \\
\hline \multirow[t]{2}{*}{ Single Male } & 0.0414 & 0.0626 & -0.1925 & -0.1811 & -0.0418 & 0.0307 \\
\hline & $(0.46)$ & $(0.51)$ & $(-2.34)$ & $(-2.25)$ & $(-0.53)$ & $(0.40)$ \\
\hline \multirow[t]{2}{*}{ Divorced } & 0.0404 & -0.2024 & -0.3082 & -0.1662 & -0.2696 & -0.2242 \\
\hline & $(0.44)$ & $(-1.76)$ & $(-3.32)$ & $(-1.81)$ & $(-3.13)$ & $(-2.77)$ \\
\hline \multirow[t]{2}{*}{ Age X Dummy for Under 35} & 0.0340 & 0.0418 & 0.0187 & 0.0310 & 0.0403 & 0.0349 \\
\hline & $(4.70)$ & $(4.41)$ & $(2.58)$ & $(4.33)$ & $(5.76)$ & $(4.78)$ \\
\hline \multirow[t]{2}{*}{ Age X Dummy for Between 35 and 55} & 0.0346 & 0.0342 & 0.0202 & 0.0318 & 0.0366 & 0.0322 \\
\hline & $(6.88)$ & $(5.11)$ & $(3.98)$ & $(6.53)$ & $(7.64)$ & $(6.54)$ \\
\hline \multirow[t]{2}{*}{ Age X Dummy for Over 55} & 0.0354 & 0.0362 & 0.0252 & 0.0313 & 0.0357 & 0.0325 \\
\hline & $(10.16)$ & $(7.75)$ & $(7.32)$ & $(9.24)$ & $(10.71)$ & (9.19) \\
\hline \multirow[t]{2}{*}{ Household size } & -0.0507 & -0.0576 & -0.0663 & -0.0741 & -0.0899 & -0.0561 \\
\hline & $(-2.40)$ & $(-2.17)$ & $(-2.87)$ & $(-3.39)$ & $(-4.17)$ & $(-2.61)$ \\
\hline \multirow[t]{2}{*}{ African American ${ }^{b}$} & -0.4816 & -0.4779 & -0.4550 & -0.5629 & -0.4640 & -0.3960 \\
\hline & $(-6.30)$ & $(-4.51)$ & $(-5.41)$ & $(-6.97)$ & $(-5.54)$ & $(-5.06)$ \\
\hline \multirow[t]{2}{*}{ Hispanic $^{b}$} & -0.1481 & -0.2959 & -0.3074 & -0.2095 & -0.0277 & -0.1158 \\
\hline & $(-1.03)$ & $(-2.17)$ & $(-2.80)$ & $(-1.89)$ & $(-0.27)$ & $(-1.24)$ \\
\hline \multirow[t]{2}{*}{ Other Race (including Asian) ${ }^{b}$} & -0.2389 & -0.4275 & 0.0568 & -0.2551 & 0.1262 & -0.2629 \\
\hline & $(-1.17)$ & $(-2.42)$ & $(0.41)$ & $(-1.84)$ & $(0.83)$ & $(-1.66)$ \\
\hline \multirow[t]{2}{*}{ Head in bad health } & -0.0147 & -0.3367 & -0.0866 & -0.1449 & -0.0892 & -0.3304 \\
\hline & $(-0.12)$ & $(-2.37)$ & $(-0.68)$ & $(-1.11)$ & $(-0.68)$ & $(-2.88)$ \\
\hline \multirow[t]{2}{*}{ Spouse in bad health } & -0.3024 & 0.2255 & -0.1623 & -0.2955 & -0.6597 & -0.2618 \\
\hline & $(-1.99)$ & $(1.03)$ & $(-0.77)$ & $(-1.67)$ & $(-3.56)$ & $(-1.48)$ \\
\hline \multirow[t]{2}{*}{ Household earned income (\$2001) } & 0.0040 & 0.0064 & 0.0067 & 0.0058 & 0.0043 & 0.0050 \\
\hline & $(1.54)$ & (3.24) & $(4.80)$ & $(4.45)$ & $(3.78)$ & $(5.16)$ \\
\hline \multirow[t]{2}{*}{ Household earned inc squared (\$2001) } & $1.89 \mathrm{E}-05$ & $-8.81 \mathrm{E}-06$ & $-7.64 \mathrm{E}-06$ & $-6.54 \mathrm{E}-06$ & $-3.94 \mathrm{E}-06$ & $-5.50 \mathrm{E}-06$ \\
\hline & $(0.74)$ & $(-2.92)$ & $(-3.89)$ & $(-4.52)$ & $(-2.99)$ & $(-4.66)$ \\
\hline \multirow[t]{2}{*}{ Head works full-time } & 0.1528 & 0.1600 & 0.1223 & 0.1021 & -0.0528 & 0.0550 \\
\hline & $(2.14)$ & $(1.27)$ & $(1.38)$ & $(1.19)$ & $(-0.62)$ & $(0.62)$ \\
\hline \multirow[t]{2}{*}{ Spouse works full-time } & -0.1228 & -0.1623 & -0.1540 & 0.0250 & -0.0939 & -0.1334 \\
\hline & $(-1.55)$ & $(-1.56)$ & $(-1.86)$ & $(0.33)$ & $(-1.28)$ & $(-1.82)$ \\
\hline \multirow[t]{2}{*}{ Spouse works part-time } & 0.0063 & -0.1540 & 0.1111 & -0.0420 & -0.0848 & -0.1405 \\
\hline & $(0.05)$ & $(-1.15)$ & $(0.98)$ & $(-0.41)$ & $(-0.75)$ & $(-1.31)$ \\
\hline \multirow[t]{2}{*}{ Head's \# full-time jobs lasting > 1 year } & -0.0587 & -0.0474 & -0.0591 & -0.0623 & -0.0396 & -0.0475 \\
\hline & $(-4.93)$ & $(-2.72)$ & $(-4.64)$ & $(-4.74)$ & $(-3.92)$ & $(-3.96)$ \\
\hline \multirow[t]{2}{*}{ Constant } & -0.6835 & -0.7547 & -0.1778 & -0.6271 & -0.7879 & -0.7848 \\
\hline & $(-3.08)$ & $(-2.44)$ & $(-0.77)$ & $(-2.74)$ & $(-3.45)$ & $(-3.25)$ \\
\hline \multirow[t]{2}{*}{ Rho } & -0.6517 & -0.9394 & -0.7179 & -0.7287 & -0.7134 & -0.7622 \\
\hline & $(-5.72)$ & $(-12.55)$ & $(-7.43)$ & $(-8.58)$ & $(-6.99)$ & $(-8.52)$ \\
\hline Uncensored obs (not credit constrained) & 2,937 & 2,516 & 2,915 & 3,244 & 3,197 & 3,356 \\
\hline Censored obs (possibly constrained) & 728 & 596 & 954 & 1,012 & 1,039 & 997 \\
\hline Log likelihood & -0.7996 & -0.8075 & -0.8355 & -0.8322 & -0.8074 & -0.8019 \\
\hline
\end{tabular}

${ }^{a}$ Reported coefficients are the actual coefficients from the bivariate probit model, not the partial derivatives. Numbers in parentheses are the t-ratios. Observations with total household earned income $\$ 1,000,000$ (in year 2001 dollars) or missing were excluded from each sample.

${ }^{b}$ Omitted category is White. 
Table A-3

Homeownership Propensity Estimated Over All Households Without Controlling for Borrowing Constraints Includes Controls for Census Region and Neighborhood Density (Partial Dervatives Are Reported) $^{a, b}$

\begin{tabular}{|c|c|c|c|}
\hline & 1992 & 1995 & 1998 \\
\hline Some college & $\begin{array}{r}0.0515 \\
(2.55)\end{array}$ & $\begin{array}{r}0.0340 \\
(1.81)\end{array}$ & $\begin{array}{r}0.0408 \\
(2.27)\end{array}$ \\
\hline College degree & $\begin{array}{r}0.0241 \\
(1.22)\end{array}$ & $\begin{array}{r}0.0304 \\
(1.57)\end{array}$ & $\begin{array}{r}0.0349 \\
(1.91)\end{array}$ \\
\hline Married & $\begin{array}{r}0.1682 \\
(6.32)\end{array}$ & $\begin{array}{r}0.1338 \\
(5.30)\end{array}$ & $\begin{array}{r}0.2023 \\
(8.65)\end{array}$ \\
\hline Single Male & $\begin{array}{r}-0.0455 \\
(-1.91)\end{array}$ & $\begin{array}{r}-0.0193 \\
(-0.87)\end{array}$ & $\begin{array}{r}0.0079 \\
(0.38)\end{array}$ \\
\hline Divorced & $\begin{array}{r}0.0221 \\
(0.88)\end{array}$ & $\begin{array}{r}0.0325 \\
(1.35)\end{array}$ & $\begin{array}{r}0.0518 \\
(2.39)\end{array}$ \\
\hline Age X Dummy for Under 35 & $\begin{array}{r}0.0071 \\
(3.33)\end{array}$ & $\begin{array}{r}0.0033 \\
(1.56)\end{array}$ & $\begin{array}{r}0.0048 \\
(2.60)\end{array}$ \\
\hline Age X Dummy for Between 35 and 55 & $\begin{array}{r}0.0096 \\
(6.48)\end{array}$ & $\begin{array}{r}0.0065 \\
(4.48)\end{array}$ & $\begin{array}{r}0.0070 \\
(5.53)\end{array}$ \\
\hline Age X Dummy for Over 55 & $\begin{array}{r}0.0089 \\
(9.01)\end{array}$ & $\begin{array}{r}0.0075 \\
(7.63)\end{array}$ & $\begin{array}{r}0.0074 \\
(8.69)\end{array}$ \\
\hline Household size & $\begin{array}{r}0.0110 \\
(1.62)\end{array}$ & $\begin{array}{r}0.0270 \\
(4.08)\end{array}$ & $\begin{array}{r}0.0170 \\
(2.65)\end{array}$ \\
\hline African American ${ }^{b}$ & $\begin{array}{r}-0.1106 \\
(-4.30)\end{array}$ & $\begin{array}{r}-0.1180 \\
(-4.89)\end{array}$ & $\begin{array}{r}-0.0834 \\
(-3.53)\end{array}$ \\
\hline Hispanic $^{b}$ & $\begin{array}{r}-0.1480 \\
(-4.56)\end{array}$ & $\begin{array}{r}-0.1441 \\
(-4.04)\end{array}$ & $\begin{array}{r}-0.1049 \\
(-3.47)\end{array}$ \\
\hline Other Race (including Asian) ${ }^{b}$ & $\begin{array}{r}-0.0935 \\
(-2.41)\end{array}$ & $\begin{array}{r}-0.1494 \\
(-3.44)\end{array}$ & $\begin{array}{r}-0.1309 \\
(-3.05)\end{array}$ \\
\hline Head in bad health & $\begin{array}{r}-0.0211 \\
(-0.65)\end{array}$ & $\begin{array}{r}-0.1021 \\
(-2.96)\end{array}$ & $\begin{array}{r}-0.0992 \\
(-2.93)\end{array}$ \\
\hline Spouse in bad health & $\begin{array}{r}-0.1019 \\
(-1.85)\end{array}$ & $\begin{array}{r}-0.0635 \\
(-1.22)\end{array}$ & $\begin{array}{r}-0.0904 \\
(-1.89)\end{array}$ \\
\hline Household earned income (\$2001) & $\begin{array}{r}0.0029 \\
(6.37)\end{array}$ & $\begin{array}{r}0.0026 \\
(5.49)\end{array}$ & $\begin{array}{r}0.0031 \\
(8.29)\end{array}$ \\
\hline Household earned inc squared (\$2001) & $\begin{array}{l}0.0000 \\
(-4.85)\end{array}$ & $\begin{array}{l}0.0000 \\
(-6.12)\end{array}$ & $\begin{array}{l}0.0000 \\
(-7.54)\end{array}$ \\
\hline Head works full-time & $\begin{array}{r}0.0970 \\
(3.85)\end{array}$ & $\begin{array}{r}0.1111 \\
(4.45)\end{array}$ & $\begin{array}{r}0.0364 \\
(1.52)\end{array}$ \\
\hline Spouse works full-time & $\begin{array}{r}-0.0005 \\
(-0.02)\end{array}$ & $\begin{array}{r}0.0532 \\
(2.45)\end{array}$ & $\begin{array}{r}0.0153 \\
(0.75)\end{array}$ \\
\hline Spouse works part-time & $\begin{array}{r}0.0217 \\
(0.70)\end{array}$ & $\begin{array}{r}0.0351 \\
(1.18)\end{array}$ & $\begin{array}{r}0.0296 \\
(0.91)\end{array}$ \\
\hline Head's \# full-time jobs lasting > 1 year & $\begin{array}{r}-0.0140 \\
(-3.85) \\
\end{array}$ & $\begin{array}{r}-0.0139 \\
(-3.89) \\
\end{array}$ & $\begin{array}{r}-0.0072 \\
(-2.40) \\
\end{array}$ \\
\hline
\end{tabular}

Continued on next page. 
Table A-3 cont.

Homeownership Propensity Estimated Over All Households

Without Controlling for Borrowing Constraints

Includes Controls for Census Region and Neighborhood Density

(Partial Dervatives Are Reported) ${ }^{a, b}$

\begin{tabular}{lrrr}
\hline & 1992 & 1995 & 1998 \\
\hline Homes on block 20 to 100 feet apart & 0.0928 & 0.1001 & 0.1197 \\
Homes on block > 100 feet apart & $(5.53)$ & $(6.09)$ & $(7.65)$ \\
NorthEast & 0.1297 & 0.1333 & 0.1061 \\
& $(5.17)$ & $(5.69)$ & $(4.66)$ \\
NorthCentral & 0.0214 & -0.0392 & $(0.76)$ \\
& $(0.88)$ & 0.0480 & 0.0707 \\
South & 0.0131 & $(2.14)$ & $(3.32)$ \\
& $(0.55)$ & 0.0401 & $(2.57)$ \\
Constant & 0.0319 & -0.512 \\
& $(1.44)$ & $(-7.91)$ & -0.5427 \\
Number of obs & -0.5702 & $(-8.55)$ \\
Log likelihood & $(-8.08)$ & -2069.8 & 4,236 \\
\hline
\end{tabular}

${ }^{a}$ Partial derivatives were calculated for each observation and then averaged over the sample applying sampling weights to ensure results are representative of the United States (see the text for details). For a given 1-0 slope variable, $X_{1-0}$, derivatives were obtained by calculating the unconditional probability of owning first with $X_{1-0}$ set equal to 1 , next with $X_{1-0}$ set equal to 0 , and then differencing the results. For all other variables derivatives were formed as $f(\mathrm{x} b) b$, where $f$ is the probability distribution function for the standard normal and $b$ is the probit model coefficient. The t-ratios in parentheses are those for the untransformed model coefficients. Observations with total household earned income above $\$ 1,000,000$ (in 2001 dollars) or missing were excluded from each sample.

${ }^{b}$ Omitted variables are White, homes on block 0 to 20 feet apart, West Region. 
Table A-4

Homeownership Propensity Estimated Over

Not Credit Constrained Households Controlling for Sample Selection Includes Controls for Census Region and Neighborhood Density (Partial Dervatives Are Reported) ${ }^{a, b}$

\begin{tabular}{|c|c|c|c|}
\hline & 1992 & 1995 & 1998 \\
\hline \multirow[t]{2}{*}{ Some college } & 0.0419 & 0.0504 & 0.0349 \\
\hline & $(1.96)$ & $(2.43)$ & $(1.82)$ \\
\hline \multirow[t]{2}{*}{ College degree } & 0.0088 & 0.0058 & 0.0277 \\
\hline & $(0.43)$ & $(0.29)$ & $(1.47)$ \\
\hline \multirow[t]{2}{*}{ Married } & 0.1486 & 0.1203 & 0.1782 \\
\hline & (5.19) & $(4.56)$ & $(7.15)$ \\
\hline \multirow[t]{2}{*}{ Single Male } & -0.0299 & 0.0183 & 0.0031 \\
\hline & $(-1.19)$ & $(0.77)$ & $(0.14)$ \\
\hline \multirow[t]{2}{*}{ Divorced } & 0.0589 & 0.0308 & 0.0609 \\
\hline & $(2.28)$ & $(1.20)$ & $(2.69)$ \\
\hline \multirow[t]{2}{*}{ Age X Dummy for Under 35} & 0.0021 & 0.0004 & 0.0018 \\
\hline & $(0.97)$ & $(0.19)$ & $(0.91)$ \\
\hline \multirow[t]{2}{*}{ Age X Dummy for Between 35 and 55} & 0.0049 & 0.0027 & 0.0039 \\
\hline & $(3.12)$ & $(1.68)$ & $(2.77)$ \\
\hline \multirow[t]{2}{*}{ Age X Dummy for Over 55} & 0.0042 & 0.0040 & 0.0041 \\
\hline & $(3.92)$ & $(3.55)$ & $(4.17)$ \\
\hline \multirow[t]{2}{*}{ Household size } & 0.0170 & 0.0292 & 0.0229 \\
\hline & $(2.28)$ & $(3.87)$ & $(2.99)$ \\
\hline \multirow[t]{2}{*}{ African American ${ }^{b}$} & -0.0634 & -0.0705 & -0.0379 \\
\hline & $(-2.06)$ & $(-2.36)$ & $(-1.34)$ \\
\hline \multirow[t]{2}{*}{ Hispanic $^{b}$} & -0.1309 & -0.1432 & -0.0993 \\
\hline & $(-3.21)$ & $(-3.45)$ & $(-2.85)$ \\
\hline \multirow[t]{2}{*}{ Other Race (including Asian) ${ }^{b}$} & -0.1191 & -0.0906 & -0.1469 \\
\hline & $(-2.87)$ & $(-1.74)$ & $(-3.12)$ \\
\hline \multirow[t]{2}{*}{ Head in bad health } & -0.0314 & -0.1120 & -0.0634 \\
\hline & $(-0.98)$ & $(-3.00)$ & $(-1.87)$ \\
\hline \multirow[t]{2}{*}{ Spouse in bad health } & -0.1206 & -0.0894 & -0.0867 \\
\hline & $(-2.04)$ & $(-1.57)$ & $(-1.58)$ \\
\hline \multirow[t]{2}{*}{ Household earned income (\$2001) } & 0.0023 & 0.0019 & 0.0022 \\
\hline & $(4.55)$ & $(3.69)$ & $(5.21)$ \\
\hline \multirow[t]{2}{*}{ Household earned inc squared (\$2001) } & 0.0000 & 0.0000 & 0.0000 \\
\hline & $(-3.91)$ & $(-4.08)$ & $(-5.19)$ \\
\hline \multirow[t]{2}{*}{ Head works full-time } & 0.0537 & 0.0695 & 0.0644 \\
\hline & $(1.89)$ & $(2.43)$ & $(2.36)$ \\
\hline \multirow[t]{2}{*}{ Spouse works full-time } & -0.0197 & 0.0419 & -0.0025 \\
\hline & $(-0.74)$ & $(1.71)$ & $(-0.11)$ \\
\hline \multirow[t]{2}{*}{ Spouse works part-time } & -0.0156 & 0.0225 & 0.0445 \\
\hline & $(-0.47)$ & $(0.71)$ & $(1.25)$ \\
\hline \multirow[t]{2}{*}{ Head's \# full-time jobs lasting > 1 year } & -0.0058 & -0.0036 & -0.0091 \\
\hline & $(-1.38)$ & $(-0.97)$ & $(-2.47)$ \\
\hline
\end{tabular}

Continued on next page. 
Table A-4 cont.

Homeownership Propensity Estimated Over

Not Credit Constrained Households Controlling for Sample Selection

Includes Controls for Census Region and Neighborhood Density

(Partial Dervatives Are Reported) ${ }^{a, b}$

\begin{tabular}{|c|c|c|c|}
\hline & 1992 & 1995 & 1998 \\
\hline Homes on block 20 to 100 feet apart & $\begin{array}{r}0.0762 \\
(4.29)\end{array}$ & $\begin{array}{r}0.0704 \\
(4.02)\end{array}$ & $\begin{array}{r}0.1049 \\
(6.05)\end{array}$ \\
\hline Homes on block $>100$ feet apart & $\begin{array}{r}0.1180 \\
(4.61)\end{array}$ & $\begin{array}{r}0.0795 \\
(3.31)\end{array}$ & $\begin{array}{r}0.0720 \\
(3.20)\end{array}$ \\
\hline NorthEast & $\begin{array}{r}-0.0431 \\
(-1.63)\end{array}$ & $\begin{array}{r}-0.0492 \\
(-1.88)\end{array}$ & $\begin{array}{r}-0.0185 \\
(-0.77)\end{array}$ \\
\hline NorthCentral & $\begin{array}{r}-0.0277 \\
(-1.06)\end{array}$ & $\begin{array}{r}0.0126 \\
(0.53)\end{array}$ & $\begin{array}{r}0.0291 \\
(1.27)\end{array}$ \\
\hline South & $\begin{array}{r}-0.0139 \\
(-0.57)\end{array}$ & $\begin{array}{r}0.0475 \\
(2.05)\end{array}$ & $\begin{array}{r}0.0438 \\
(2.05)\end{array}$ \\
\hline Constant & $\begin{array}{r}-0.1866 \\
(-2.36)\end{array}$ & $\begin{array}{r}-0.2093 \\
(-2.54)\end{array}$ & $\begin{array}{r}-0.2794 \\
(-3.53)\end{array}$ \\
\hline Rho & $\begin{array}{r}-0.7212 \\
(6.87) \\
\end{array}$ & $\begin{array}{r}-0.7157 \\
(-8.15) \\
\end{array}$ & $\begin{array}{r}-0.6204 \\
(-4.92)\end{array}$ \\
\hline Uncensored obs (not credit constrained) & 2,915 & 3,244 & 3,197 \\
\hline Censored obs (possibly constrained) & 954 & 1,012 & 1,039 \\
\hline Log likelihood & -0.8270 & -0.8240 & -0.7931 \\
\hline \multicolumn{4}{|c|}{$\begin{array}{l}{ }^{a} \text { Partial derivatives were calculated for each observation and then averaged over the sample applying } \\
\text { sampling weights to ensure results are representative of the United States (see the text for details). For } \\
\text { a given } 1-0 \text { slope variable, } X_{1-0} \text {, derivatives were obtained by calculating the unconditional probability } \\
\text { of owning first with } X_{1-0} \text { set equal to } 1 \text {, next with } X_{1-0} \text { set equal to } 0 \text {, and then differencing the results. } \\
\text { For all other variables derivatives were formed as } f(x b) b \text {, where } f \text { is the probability distribution } \\
\text { function for the standard normal and } b \text { is the probit model coefficient. The t-ratios in parentheses are } \\
\text { those for the untransformed model coefficients. Observations with total household earned income } \\
\text { above } \$ 1,000,000 \text { (in } 2001 \text { dollars) or missing were excluded from each sample. }\end{array}$} \\
\hline
\end{tabular}

